\title{
Aqueous Chemical Co-Precipitation of Iron Oxide Magnetic Nanoparticles for Use in Agricultural Technologies
}

\author{
Olga A. Shilova ${ }^{1.2, *(\mathbb{C})}$, Gayane Panova ${ }^{3(\mathbb{D})}$, Anton Nikolaev ${ }^{1(\mathbb{D})}$, Anastasia Kovalenko ${ }^{1}{ }^{(\mathbb{D}}$, Alexandr \\ Sinelnikov ${ }^{4}$, Gennady Kopitsa ${ }^{\text {5(D), Alexandr Baranchikov }}{ }^{(\mathbb{D}}$, Olga Udalova ${ }^{3(\mathbb{D})}$, Anna Artemyeva ${ }^{7(\mathbb{C})}$, \\ Dmitry Kornyuchin ${ }^{7(\mathbb{D})}$, Lyudmila Anikina ${ }^{3(\mathbb{D})}$, Anna Zhuravleva ${ }^{3(\mathbb{D}}$, Yuriy Khomyakov ${ }^{(\mathbb{D})}$, Vitalyi \\ Vertebnyi $^{3}$ (i), Victoria Dubovitskaya ${ }^{3}$ (D), Tamara Khamova ${ }^{1}$ (i) \\ Institute of Silicate Chemistry of Russian Academy of Sciences, St. Petersburg, Russia \\ Saint-Petersburg State Electrotechnical University "LETI", Saint-Petersburg, Russia \\ Agrophysical Research Institute, St. Petersburg, Russia \\ 4 Voronezh State University, Voronezh, Russia \\ 5 Petersburg Nuclear Physical Institute named by B.P. Konstantinov of National Research Centre "Kurchatov Institute", \\ Gatchina, Leningrad Region, Russia \\ 6 Kurnakov Institute of General and Inorganic Chemistry of the Russian Academy of Sciences, Moscow, Russia \\ * Correspondence: olgashilova@bk.ru;
}

Received: 1.10.2020; Revised: 21.10.2020; Accepted: 22.10.2020; Published: 25.10.2020

\begin{abstract}
Magnetic nanoparticles of iron oxides were obtained by precipitation from aqueous solutions of iron chlorides $\left(\mathrm{Fe}^{2+} / \mathrm{Fe}^{3+}\right)$. It is shown that, depending on the use of various technological techniques in their synthesis (ultrasound, bubbling with argon, heating, the addition of oleic acid), nanoparticles 5$40 \mathrm{~nm}$ in size, spherical or plate-like, with a specific surface area of 52-92 $\mathrm{m}^{2} / \mathrm{g}$, are formed corresponding to maghemite or solid solutions of maghemite with magnetite. The latter, in particular, are synthesized with a shell of oleic acid. Aqueous suspensions of nanoparticles ( 0.00001 to $100 \mathrm{mg} / \mathrm{L})$ were used for the pre-sowing treatment of seeds of spring barley, cabbage, and salad crops, as well as for foliar treatment $(0.001$ to $1 \mathrm{mg} / \mathrm{L})$ of vegetative cucumber and lettuce plants. It was found that these nanoparticles do not possess fungicidal and bactericidal activity against pathogens (Xanthomonas campestris pv. campestris (Pammel) Dowson) of cabbage vascular bacteriosis, barley dark brown spot, and root rot (Cochliobolus sativus (S. Ito \& Kurler ex.) Drechs. Dastur), but exhibit weak fungicidal activity in certain concentrations, in particular, against the causative agents of blackleg in white cabbage. Presowing seed treatment, in general, has a positive effect on germination and morphometric parameters of different plants. These parameters significantly depend on the concentration of nanoparticles in suspensions, their phase composition, and the presence or absence of an inert shell on the surface. Foliar treatments of cucumber and lettuce seedlings with suspensions of synthesized nanoparticles improved the morphometric and biochemical parameters of plants, which together provide a tendency to increase their productivity, which is more pronounced at a nanoparticle concentration of $0.01 \mathrm{mg} / \mathrm{L}$. In the future, it is possible to further enhance the phytoprotective effect of iron oxide nanoparticles, which will reduce the dose load of persistent agrochemicals and pesticides on the environment.
\end{abstract}

Keywords: nanoparticles; magnetite; maghemite; precipitation; pre-sowing treatment; foliat treatment; morphometric parameters.

\footnotetext{
(C) 2020 by the authors. This article is an open-access article distributed under the terms and conditions of the Creative Commons Attribution (CC BY) license (https://creativecommons.org/licenses/by/4.0/).
} 


\section{Introduction}

Using synthetic nanoparticles in agriculture as bioactive stimulators and fertilizers are one of the prospective fields of research and therefore attracts a lot of attention from scientists [1]. The positive influence of the nanoparticles on the plants includes photocatalytic activity, an increase of the chlorophyll content, germination, and growth stimulation [2-8]. There is evidence that nanoparticles can suppress plants in different ways: slowed growth, oxygen stress, impaired photosynthesis, water transport disturbance, increasing of the sensibility to the natural toxins [9-11]. But the researchers point out that nanoparticles influence plants via several mechanisms at once, and the behavior of the nanoparticles in the environment itself is regulated by the complicated principles, so the interaction between a specific plant and specific nanoparticles should be studied in every single case [12].

Iron plays an important role in the plant metabolism: it increases growth rate, length of leaves, chlorophyll content; it decreases the content of the hydrogen peroxide and therefore decreases lipids oxidation [3]. Researchers state that although iron can be used as the fertilizer in the form of nanoparticles of metallic $\mathrm{Fe}$ [6, 13-14], still, the $\mathrm{Fe}_{\mathrm{x}} \mathrm{O}_{\mathrm{y}}$ oxides are the main usable form of it $[3,9,12,14-17]$. Particularly, one of the most used forms of iron oxide is the maghemite - magnetic modification $\gamma-\mathrm{Fe}_{2} \mathrm{O}_{3}$.

It is worth noting that maghemite nanopowders can be used for the solution of multiple problems: cleaning water from oil products [18, 19], utilizing maghemite in biomedical applications as the contrasting agent for magnetic resonance imaging, hyperthermia, and drug delivery [20-23]. These applications were developed earlier than agricultural ones, so the possibility of using maghemite in agricultural technologies arose only recently $[3,6,12,14$, $19,24]$. In this case, commercial end-products are often used, the composition and properties of which are practically not described, as well as detailed data on products based on these nanoparticles are not provided. Until now, there are conflicting opinions as to whether magnetite or maghemite is better (safer and / or more efficient) to use in agricultural technologies. One of the areas of research is the use of commercial or specially synthesized nanoparticles of metal oxides, with functional layers (shells) created on their surface, which make it possible to achieve better aggregate stability of the products on their basis, contain nutrients for plants, improve biocompatibility with seeds or plants, reduce the toxic effect of nanoparticles. Most authors are inclined to believe that it is necessary to study the effect of nanoparticles on each plant species separately, taking into account the peculiarities of the composition and structure of nanoparticles, studying their effect in a wide range of concentrations used for treating seeds or plants.

The aim of this work was to synthesize magnetic nanoparticles (maghemite and / or magnetite) to study their physicochemical and biological properties for the development and improvement of technological methods for pre-sowing and foliar treatment of seeds and vegetative plants. To achieve this goal, it was necessary to solve the following tasks:

- to synthesize and characterize magnetic nanoparticles of maghemite and / or magnetite, differing in a number of basic characteristics: phase composition, size, morphology, texture, and surface additives;

- to identify whether these nanoparticles have bactericidal and / or fungicidal properties, whether they affect the resistance of plants to phytopathogens (for example, white cabbage);

- to reveal how the pre-sowing treatment of seeds with aqueous suspensions of the obtained magnetic nanoparticles of iron oxides, depending on their composition, morphology, 
texture, concentration, affects germination and morphometric characteristics at the early stages of development of the following important agricultural plants: spring barley; garden cress; vegetable brassicas - white cabbage, cauliflower;

- to establish how the foliar treatment with aqueous suspensions of the obtained magnetic nanoparticles affects the morphometric, physiological, and biochemical parameters of vegetable crops using the example of cucumber and lettuce when growing plants under controlled conditions of intensive light culture.

\section{Materials and Methods}

\subsection{Synthesis of nanopowders}

Based on the literature data [25-29] and our own experience [30-33], we synthesized magnetic iron oxide nanopowders using three techniques of chemical deposition from aqueous solutions of iron (II, III) salts.

1st technique. Aqueous solutions of iron chlorides $\mathrm{FeCl}_{2}$ and $\mathrm{FeCl}_{3}$ were mixed at room temperature in a molar ratio $\mathrm{FeCl}_{2}: \mathrm{FeCl}_{3}=1: 2$. Then an aqueous ammonia solution $(12.5 \mathrm{wt}$.\%) was gradually added. According to the chemical reaction, magnetite should be obtained:

$$
\mathrm{FeCl}_{2}+2 \mathrm{FeCl}_{3}+8 \mathrm{NH}_{4} \mathrm{OH}=\mathrm{Fe}_{3} \mathrm{O}_{4}+8 \mathrm{NH}_{4} \mathrm{Cl}+4 \mathrm{H}_{2} \mathrm{O} \text {. }
$$

Since it is known about the successful use of maghemite for the treatment of plant seedlings [3], we tried to oxidize magnetite and obtain precisely maghemite $\gamma$ - $\mathrm{Fe}_{2} \mathrm{O}_{3}$ nanopowder:

$$
4 \mathrm{Fe}_{3} \mathrm{O}_{4}+\mathrm{O}_{2}=6 \mathrm{Fe}_{2} \mathrm{O}_{3}
$$

To promote the oxidation of magnetite to maghemite, the precipitation process was carried out under the influence of ultrasound $(240 \mathrm{~W}, 40 \mathrm{kHz})$ for 30 minutes. The powder from the resulting suspension was extracted by magnetic separation using a neodymium magnet, washed with water, and dried at $100{ }^{\circ} \mathrm{C}$ for $24 \mathrm{~h}$. The synthesis scheme is shown in Fig. 1 - 1 st technique.

2nd technique. Aqueous solutions of iron chlorides $\mathrm{FeCl}_{2}$ and $\mathrm{FeCl}_{3}$ in the same molar ratio were mixed with constant bubbling with argon. To intensify the process of nanopowder deposition with an aqueous solution of ammonia (6.25 wt\%), it was carried out under bubbling with argon and at an elevated temperature of $60^{\circ} \mathrm{C}$. The powder from the resulting suspension was extracted by magnetic separation using a neodymium magnet, washed with water, and dried at $100{ }^{\circ} \mathrm{C}$ for $24 \mathrm{~h}$. The synthesis scheme is shown in Fig. $1-2$ nd technique.

3rd technique. This technique was identical to the second one until the deposition of the magnetic powder. Then, several operations were carried out to create a shell of oleic acid, which was designed to mitigate the possible aggressive effect of magnetic iron oxide nanoparticles on plants. For this, $1 \mathrm{ml}$ of oleic acid was added to the freshly formed precipitate.

The mixture was vigorously stirred with a magnetic stirrer for 1 hour at a temperature of $50{ }^{\circ} \mathrm{C}$. The precipitate was recovered from the solution, not by magnetic separation, but by decantation, then washed with water, and dried at $100{ }^{\circ} \mathrm{C}$ for $24 \mathrm{~h}$. The synthesis scheme is shown in Fig. 1 - 3rd technique. 

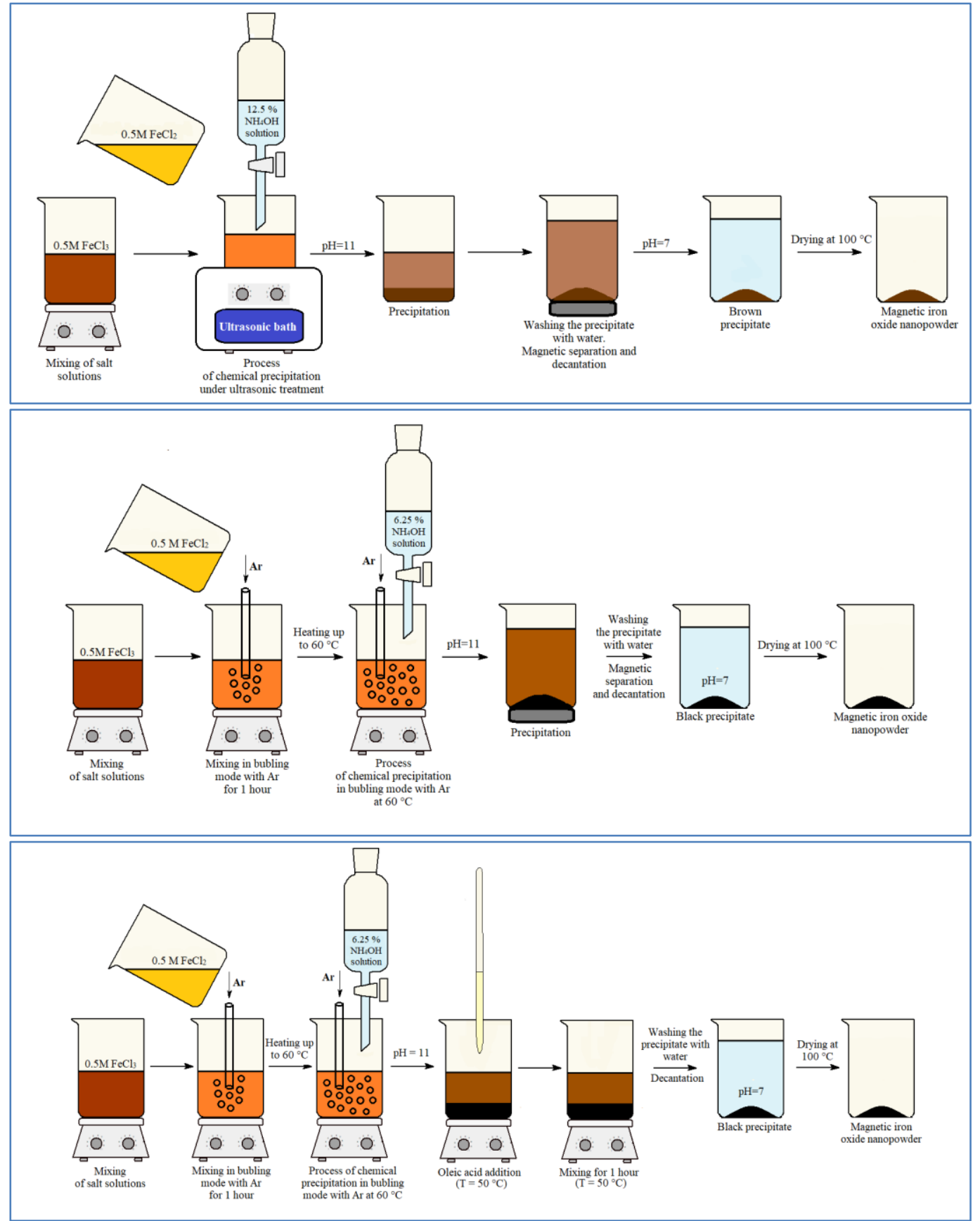

Figure 1. Three schemes of chemical synthesis of magnetic powders of iron oxides, differing by the methods of co-precipitation process intensification.

2.2. Physicochemical methods for studying the phase composition, morphology, and texture of nanopowders.

The phase composition and crystal structure of the powders were studied via powder $\mathrm{X}$-ray diffraction using a Bruker D8-Advance diffractometer $\left(\mathrm{CuK} \alpha\right.$ radiation, range $20-80^{\circ}$ $2 \theta$, step $0.0075^{\circ}$, exposure $7 \mathrm{~s}$ ). The lattice parameters were calculated via the least-squares method using the PDWin software package.

Since the powders turned out to be nanosized, FTIR spectroscopy was used to identify the phase composition, which was also used to confirm the presence of oleic acid on the surface of the powder nanoparticles. The measurements were performed using Infraspec FSM 2202 spectrometer. $1 \mathrm{mg}$ of the sample was pressed with $200 \mathrm{mg}$ of $\mathrm{KBr}$ in the tablet; measurement was carried out in the wavelength range $400-4000 \mathrm{~cm}^{-1}$. 
The morphology of nanoparticles (size, shape, and degree of their aggregation) was studied via scanning electron microscopy (SEM), which was carried out by means of a scanning electron microscope with a field emission cathode (FE-SEM) ZeissMerlin, as well as using high-resolution transmission electron microscopy (TEM) carried out by means of ZEISS Libra 120 transmission electron microscope at the Centre for Collective Use of Scientific Equipment (CCUSE).

The measurements of the specific surface area of nanopowders were performed by lowtemperature nitrogen adsorption using QuantaChrome Nova 1200e analyzer. The samples were degassed at $150{ }^{\circ} \mathrm{C}$ in a vacuum for $17 \mathrm{~h}$ prior to analysis. Based on the data obtained, the specific surface area SBET was calculated for the samples using the Brunauer-Emmett-Teller model (BET) and the seven points technique within the relative pressure range of $\mathrm{P} / \mathrm{P}_{0}=0.07$ $\div 0.25$ (where $\mathrm{P}_{0}$ is the saturation pressure). The calculation of the pore size distribution was carried out on the basis of nitrogen isotherms using the Barrett-Joyner-Halenda (BJH) technique.

\subsection{The investigation of the aggregate stability of suspensions by colloidal techniques.}

Since magnetic nanoparticles of iron oxides were supposed to be used for treating seeds and plants in the form of aqueous suspensions, it was useful to assess their aggregate stability. On the basis of iron oxide nanopowders, aqueous suspensions with a concentration of 0.1 $\mathrm{mg} / \mathrm{ml}$ were prepared. To achieve better dispersion of nanoparticles in water, the powders were exposed to ultrasound in an ultrasonic bath $(240 \mathrm{~W}, 40 \mathrm{kHz})$ for 20 minutes. Freshly prepared suspensions were muddy and highly concentrated. Therefore, they were left for 3 days to achieve aggregate and sedimentation stability. Then, the aggregate stability of the supernatant was measured by measuring the average hydrodynamic diameter of nanoparticles in an aqueous suspension using the dynamic light scattering technique by means of NanoBrook 90 PlusZeta device.

Due to the fact that some suspensions had larger mean hydrodynamic diameters than the device allowed to measure, all suspensions were additionally diluted 10 times and, after ultrasonic treatment for 20 minutes, were measured again. Subsequently, the suspensions, both after the first and after the second dilution, were tested for aggregation stability after 1 week, after 1 month, and after 4 months. Such an interest in the size of the aggregate in the water suspensions is due to the importance of the water suspensions for the pre-sowing and foliar treatment.

2.4. Biological, microbiological, and biochemical techniques for studying the properties of magnetic nanoparticles of iron oxides and their effect on biological objects.

2.4.1. The evaluation of the bactericidal and fungicidal properties of magnetic iron oxide nanoparticles.

The fungicidal and bactericidal properties of the investigated magnetic nanoparticles of iron oxides were evaluated using two phytopathogens as test objects: a) the causative agent of vascular bacteriosis of cabbage Xanthomonas campestris pv. campestris (Pammel) Dowson, strain 5212 ; b) the causative agent of barley dark brown spotting and barley root rot, the micromycete Cochliobolus sativus (S. Ito \& Kurib.) Drechsler ex Dastur. The solutions of the preparations were mixed in distilled water; for making the stock solutions, an Elmasonic S30H 
ultrasonic bath was used, into which a glass test tube with a substance and a solvent was immersed for 30 minutes.

Evaluation of the magnetic iron oxide nanoparticles fungicidal activity was carried out on pure cultures of phytopathogenic fungi by the dilution technique using Czapek's nutrient medium with lactose and urea as modified by Benken et al. [34]. The solution of the preparation was added to the specified medium, poured into 12-well plates, $2 \mathrm{ml}$ in each well, and cooled to $45^{\circ} \mathrm{C}$. After solidification, a spore suspension of a phytopathogenic fungus was applied to the surface of the medium under sterile conditions at a concentration of 30 thousand spores per $1 \mathrm{ml}$ of the medium or $50 \mu \mathrm{l}$ per dish. After keeping Petri dishes with applied test objects in a sterile cabinet for 1 day at a temperature of $25^{\circ} \mathrm{C}$, the germination of spores on the surface of the medium was assessed in comparison with the control using an inverted microscope Biolam P1.

The bactericidal activity of magnetic iron oxide nanoparticles was assessed according to the technique of A.N. Ignatov [35]: a culture of phytopathogenic bacteria was incubated in a modified liquid King B medium containing the preparation for 36 hours at $28{ }^{\circ} \mathrm{C}$, followed by plating on a solid nutrient medium of the same composition for testing the viability of the bacterial samples exposed to the preparation. The growth of colonies of the bacterial phytopathogen was counted after 72 hours. The bactericidal effect of the preparations was judged by the presence or absence of growth on the fourth day on the solid medium. The tests were carried out in duplicate.

2.4.2. The assessment of the biological activity of magnetic iron oxide nanoparticles and their effect on biological objects.

The study of the iron oxides magnetic nanoparticles biological activity consisted of determining the influence of treating the number of vegetable and grain crops seeds on their germination energy, germination rate (GOST 12038-84), as well as through the influence of the treatment of seeds and foliar effects on the plants morphophysiological characteristics during the vegetative period. In a number of experiments, the effect of the treatment of phytotest objects seeds with synthesized substances on the plant's resistance to damage by major phytopathogenic microorganisms was evaluated.

The phytotest objects of research were seeds and / or vegetative plants of spring barley, zoned in the Leningrad region, as well as cabbage crops: white cabbage variety Penca de Povoa (k-2558, Portugal), cauliflower variety Hobart (k-874, UK); garden cress variety Azhur and a number of varieties and hybrids of vegetable crops, more adapted to the controlled conditions of intensive light culture, lettuce of Typhoon and cucumber hybrid F1 Neva. The crops seeds were obtained from the collections of the N.I. Vavilov All-Russian Institute of Plant Genetic Resources (VIR) and Russian seed breeding companies (JSC "Agricultural selection and production enterprise" Sortsemovosch, Gavrish).

The assessment of the effect of synthesized magnetic nanoparticles of iron oxides on plants was carried out at the Agrophysical Research Institute (St. Petersburg), in laboratory conditions and on a special biopolygon under controlled conditions of intensive light culture, as well as in VIR greenhouses.

Presowing seed treatment was carried out by mixing for 10 min via simple shaking the seeds in containers with water (control), as well as with the mentioned above aqueous suspensions with different contents of synthesized iron oxides from 0.00001 to $100 \mathrm{mg} / \mathrm{L}$. Suspensions were prepared using an ultrasonic bath. This technique was especially necessary 
for nanoparticles coated with oleic acid since they did not mix well with water. The seeds were dried at room temperature in air and then at $30{ }^{\circ} \mathrm{C}$ for 60 minutes in an oven. Seed drying regimes corresponded to those specified in GOST 12038. Treated seeds were stored at room temperature before sowing. The repetition of the experiment was 400 seeds for each variant of the experiment.

Foliar treatment with aqueous suspensions of iron oxides magnetic nanoparticles in concentrations of $0.001-1 \mathrm{mg}$ was carried out three times every 5 days after the previous for each stage of 3-5 true leaves development in a series of experiments during the period of vegetative growth of cucumber hybrid F1 the Neva and lettuce variety Typhoon seedlings. In the control variant, the plants were treated with water.

2.4.2.1. The assessment for the effect of test crops seed treatment with synthesized substances on plant resistance to damage by major phytopathogenic microorganisms.

White cabbage cultivar Penca de Povoa (k-2558, Portugal) was used as phytotest object. Its seeds were pretreated with iron oxides magnetic nanoparticles aqueous suspensions in various concentrations. The seeds were planted on a substrate infected with cabbage blackleg pathogens - micromycetes Pyhtium debaryanum Hesse, Olpidium brassicae Wor., Phizoctonia aderholdii Kolosh., Leptosphaeria maculans (Sowerby) P. Karst., Fusarium sp). Cabbage seeds treated with the mentioned aqueous suspensions and sown in cassettes with autoclaved non-contaminated soil served as background controls. Seeds treated with distilled water and sown on non-contaminated soil served as a general control without contamination. The plants were cultivated for 21 days in a growing chamber at a constant air temperature of $18{ }^{\circ} \mathrm{C}$ and light day/night mode $-16 \mathrm{~h} / 8 \mathrm{~h}$. At the end of the experiment, two indicators were taken into account - the number of plants and the degree of damage on the VIR scale (1 - no damage, 3 mild symptoms, 5 - typical symptoms, 7 - severe symptoms, necrosis, 9 - lack of seedlings) according to the VIR methodological instructions [36]. In this case, the weighted average defeat score for the variants was calculated according to the formula: $M=\sum\left(a^{*} b\right) / N$, where $\sum\left(a^{*} b\right)$ is the sum of the affected variants multiplied by the corresponding defeat score, $\mathrm{N}$ is the total number of variants [36].

\subsubsection{The evaluation of the biological activity of magnetic iron oxide nanoparticles.}

Seeds of phytotest objects were germinated in Petri dishes $10 \mathrm{~cm}$ in diameter on filter paper soaked in $10 \mathrm{ml}$ of an aqueous solution of the test substance. In the control variants, the seeds were germinated in distilled water. On the 3rd day, the energy of seed germination was assessed; on the 7th day - their germination rate (GOST 12038-84) and the length of shoots and roots of seedlings were also measured. The studies were carried out in accordance with the rules of the International Seed Testing Association (ISTA) and generally accepted methods $[37,38]$. All experiments were repeated three times.

\subsubsection{Methodology for conducting vegetation experiments.}

In a series of vegetation experiments under controlled conditions on the biopolygon of the Agrophysical Research Institute, the seedlings of cucumber or lettuce were cultivated in a plant growing light equipment [39] with light blocks lifting along the vertical axis containing light sources - gas-discharge mirrored sodium lamps DNaZ-400 (Reflux, Russia). Irradiation in the useful area in the field of photosynthetically active radiation was $80-90 \mathrm{~W} / \mathrm{m}^{2}$, the 
duration of the light period was $14 \mathrm{~h}$. The air temperature was maintained within the range of $+22 \ldots+24^{\circ} \mathrm{C}$ during the day and $+18 \ldots+20{ }^{\circ} \mathrm{C}$ at night, the relative humidity of the air - at the level of $65-75 \%$. Seedlings of phytotest objects were grown on a small-volume analog of soil "Agrophyte" [40] with the Knop's nutrient solution applied to it [41] via the drip irrigation technique. The number of lettuce plants - 5 pieces/tray, cucumber - 1 piece/container, replication - 20 plants per each variant of the experiment. After three consecutive foliar treatments, carried out during the stages of 3-5 true leaves development, the harvesting of plants was carried out at the beginning of 6th leaf development of cucumber and the beginning of 10-11 leaf of lettuce. Vegetation experiments were carried out in duplicate. When harvesting, the height of the plants, the number and size of leaves, the leaf area, the wet and dry weight of the above-ground part of the plants, and the percentage of dry matter were taken into account. The biochemical composition of plants, namely the content of chlorophyll and carotenoid pigments in the leaves, as well as trace elements (iron, copper, manganese, and zinc), was determined in the Testing Laboratory of the Agrophysical Research Institute. The determinations were carried out in accordance with the requirements of modern regulatory documents and generally accepted methods [42, 43].

Statistical data processing was carried out using Excel 2010 and Statistica 8 programs (Stat-Soft, Inc., USA). The mean values of the studied indicators, confidence intervals, and coefficients of variation were determined. The significance of differences between the options was assessed using parametric statistics methods (Student's t-test). Differences between the options were considered significant at $\mathrm{p} \leq 0.05$.

\section{Results and Discussion}

\subsection{Phase composition of nanopowders.}

The results of the X-ray phase analysis are shown in Fig. 2. As can be seen from the Xray diffraction patterns, they are almost identical. Broad peaks characteristic of nanoparticles is observed in all three variants.

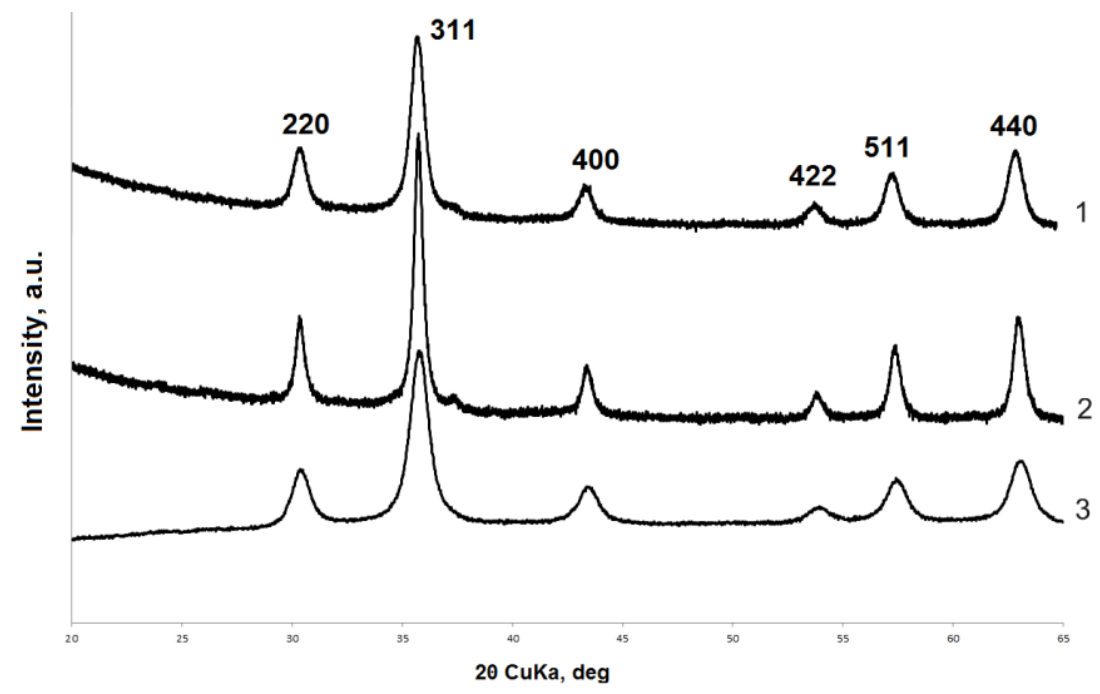

Figure 2. X-ray diffraction patterns of magnetic nanopowders synthesized by techniques 1, 2, and 3 .

$\mathrm{X}$-ray phase analysis showed that all powders correspond in composition to magnetite and/or maghemite and do not contain more than 5\% impurities of any other phase (Fig. 2). Both maghemite and magnetite share a common crystal lattice structure. Therefore, it was not 
possible to distinguish magnetite from maghemite based only on the analysis of the position of the peaks in the diffractograms of nanopowders. However, a comparison of the unit cell parameters makes it possible to distinguish magnetite from maghemite [31, 43-46]. This was done in this study. The results of calculating the parameters of unit cells for the synthesized iron oxides are given in Table 1, along with literature data and data for natural magnetite and commercial magnetite nanopowders.

The obtained data indicate solid solutions of maghemite and magnetite were obtained during the syntheses in all three variants. Indeed, if magnetite and maghemite are isostructural, then the chemical formula of maghemite can be represented as $\mathrm{Fe}_{(3-1 / 3)} \mathrm{O}_{4}$, and the formula of the solid solution as $\mathrm{Fe}_{(3-\delta)} \mathrm{O}_{4}$, where $\delta \leq 1 / 3$ [31, 47]. Using the dependence of the parameter a (the size of the unit cell of the crystal lattice) on the number of vacancies in the crystal structure, it is possible to determine to which crystalline modification the resulting nanopowder is closer (Fig. 3, Table 1). The straight-line equation has the form of $y=0.1818 x+7.8505$. Substituting the value of the parameter into this equation, we get the value of $\delta$.

Based on the values of the crystal lattice parameters, it can be concluded that the nanopowder precipitated from aqueous solutions of iron salts using ultrasonic action and isolated from the mother liquor by magnetic separation (technique 1) is very close in phase composition to maghemite. For nanopowders deposited with continuous bubbling with argon and heating to $60{ }^{\circ} \mathrm{C}$ (techniques 2 and 3), the preparation methods of which are almost identical and differed only in the presence or absence of oleic acid addition, and different methods of precipitation separation from the mother liquor (magnetic separation or decantation), it is possible to state that they correspond to the composition of the maghemitemagnetite solid solution, but also nevertheless closer to maghemite. In this case, apparently, the action of the inert gas argon prevented complete oxidation of iron to the trivalent state.

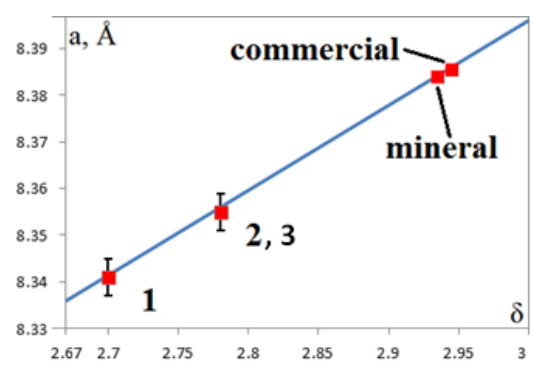

Figure 3. Dependence of the parameter $a$ of the unit cell of the crystal lattice of iron oxides on the number of vacancies $(\delta)$ in the structure of the solid solution. The line is drawn according to the data of Nasrazadani \& Raman [41].

Table 1. Unit cell parameters for nanopowders obtained by techniques 1, 2, and 3, in comparison with experimental data for natural and commercial magnetite and literature data.

\begin{tabular}{l|l} 
Name & $\boldsymbol{a}, \mathbf{\AA}$ \\
\hline Maghemite $\left.\gamma-\mathrm{Fe}_{2} \mathrm{O}_{3}[37,39]\right]$ & $8.336-8.339$ \\
\hline $\begin{array}{l}\text { Nanopowder, synthesized } \\
\text { via technique 1 }\end{array}$ & \\
\hline via techniques 2 and 3 (with oleic acid) & $8.341 \pm 0.004$ \\
\hline & $8.355 \pm 0.004$ \\
\hline & \\
Mineral magnetite* & $8.3840 \pm 0.0003$ \\
Commercial magnetite * & $8.3855 \pm 0.0002$ \\
Magnetite $\mathrm{Fe}_{3} \mathrm{O}_{4}[39,42]$ & $8.396-8.397$
\end{tabular}

*/The data were obtained by the authors for natural magnetite (Kovdorskoe deposit, Kola Peninsula, Russia) and commercial magnetite (Sigma-Aldrich, CAS N 1317-61-9). 
The presence of oleic acid on the surface of iron oxide nanoparticles obtained by technique 3 was confirmed by IR spectroscopy data (Fig. 4). The spectrum of sample 3 contains absorption bands that correspond to the functional groups of oleic acid [48, 49].

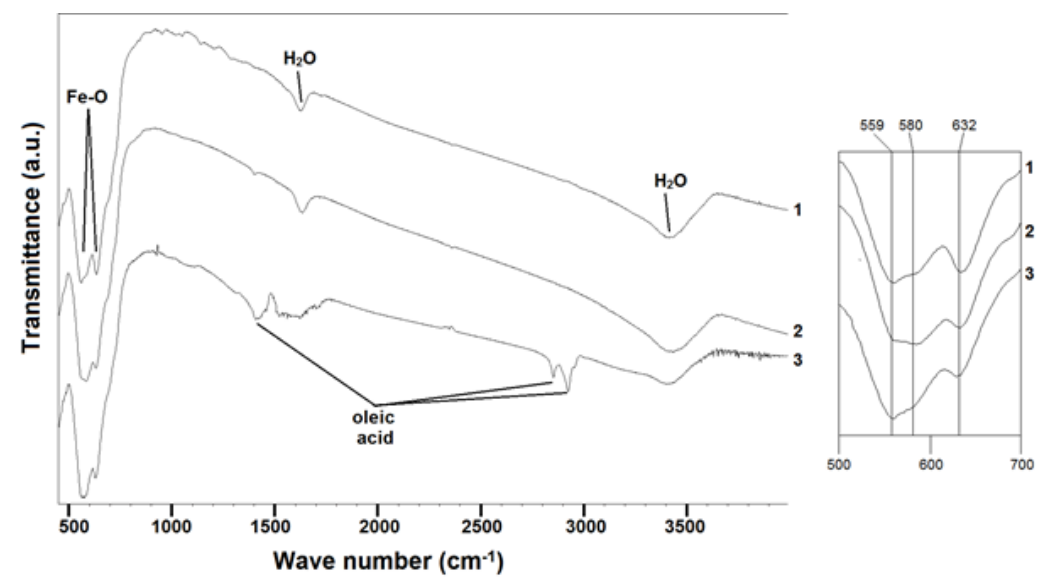

Figure 4. IR spectra of nanopowders obtained via techniques 1 and 2 (without oleic acid) and 3 (with oleic acid).

The bands at 2927 and $2852 \mathrm{~cm}^{-1}$ correspond to vibrations of the $\mathrm{CH}_{2}$ group (asymmetric and symmetric vibrations, respectively), the band at $1706 \mathrm{~cm}^{-1}$ to the vibrations of $\mathrm{C}=\mathrm{O}$, and the band at $1409 \mathrm{~cm}^{-1}$ to the vibrations of the $\mathrm{CH}_{3}$ group.

It is known [50-55] that maghemite is characterized by bands at 559 and $632 \mathrm{~cm}^{-1}$, and magnetite - at $580 \mathrm{~cm}^{-1}$. Thus, we can conclude that in both cases, we are dealing with solid solutions of iron oxides maghemite and magnetite. However, the sample obtained by technique 1 is closest in phase composition to maghemite since the size of the elementary parameter, a crystal lattice, is very close to the parameters of maghemite.

In what follows, for the convenience of presenting the results of the powder nanoparticles synthesized by technique 1 study, we will identify as maghemite and denote it as $\gamma-\mathrm{Fe}_{2} \mathrm{O}_{3}$, and powder nanoparticles synthesized by methods 2 and 3 as nanoparticles corresponding in composition to the maghemite-magnetite solid solution $\gamma-\mathrm{Fe}_{2} \mathrm{O}_{3}-\mathrm{Fe}_{3} \mathrm{O}_{4}$ without a shell and with a shell of oleic acid: $\gamma-\mathrm{Fe}_{2} \mathrm{O}_{3}-\mathrm{Fe}_{3} \mathrm{O}_{4} @$ oleic acid.

\subsection{Morphology of nanoparticles of powders.}

SEM images of the surface of powder nanoparticles are shown in Fig. 5. These images do not give a complete picture of the size and shape of powder nanoparticles. However, already being guided by them, it can be concluded that nanoparticles in powders are agglomerated regardless of the preparation technique.

To better assess the morphology and size of nanoparticles, they were examined using high-resolution transmission microscopy (Fig. 6).

As can be seen from Fig. 6, nanoparticles of the $\gamma-\mathrm{Fe}_{2} \mathrm{O}_{3}$ powder obtained under ultrasonic action in the absence of oleic acid and isolated from the mother liquor by means of magnetic separation (technique 1) turned out to be larger, with a spread in size from 5-10 to 20 and even up to $\sim 40 \mathrm{~nm}$; they have a shape close to spherical. In contrast to them, nanoparticles of $\gamma-\mathrm{Fe}_{2} \mathrm{O}_{3}-\mathrm{Fe}_{3} \mathrm{O}_{4}$ and $\gamma-\mathrm{Fe}_{2} \mathrm{O}_{3}-\mathrm{Fe}_{3} \mathrm{O}_{4} @$ oleic acid powders were obtained by bubbling with argon with heating $\left(60{ }^{\circ} \mathrm{C}\right)$, regardless of how they were isolated from the mother liquor (techniques 2 and 3) turned out to be smaller in size - from 5 to $20 \mathrm{~nm}$. An increase in the size of nanoparticles obtained by technique 3 (with oleic acid) in comparison with nanoparticles 
obtained by identical technique 2 (without oleic acid) occurs due to the shell of oleic acid, which is clearly visible on Fig. 6 (2).

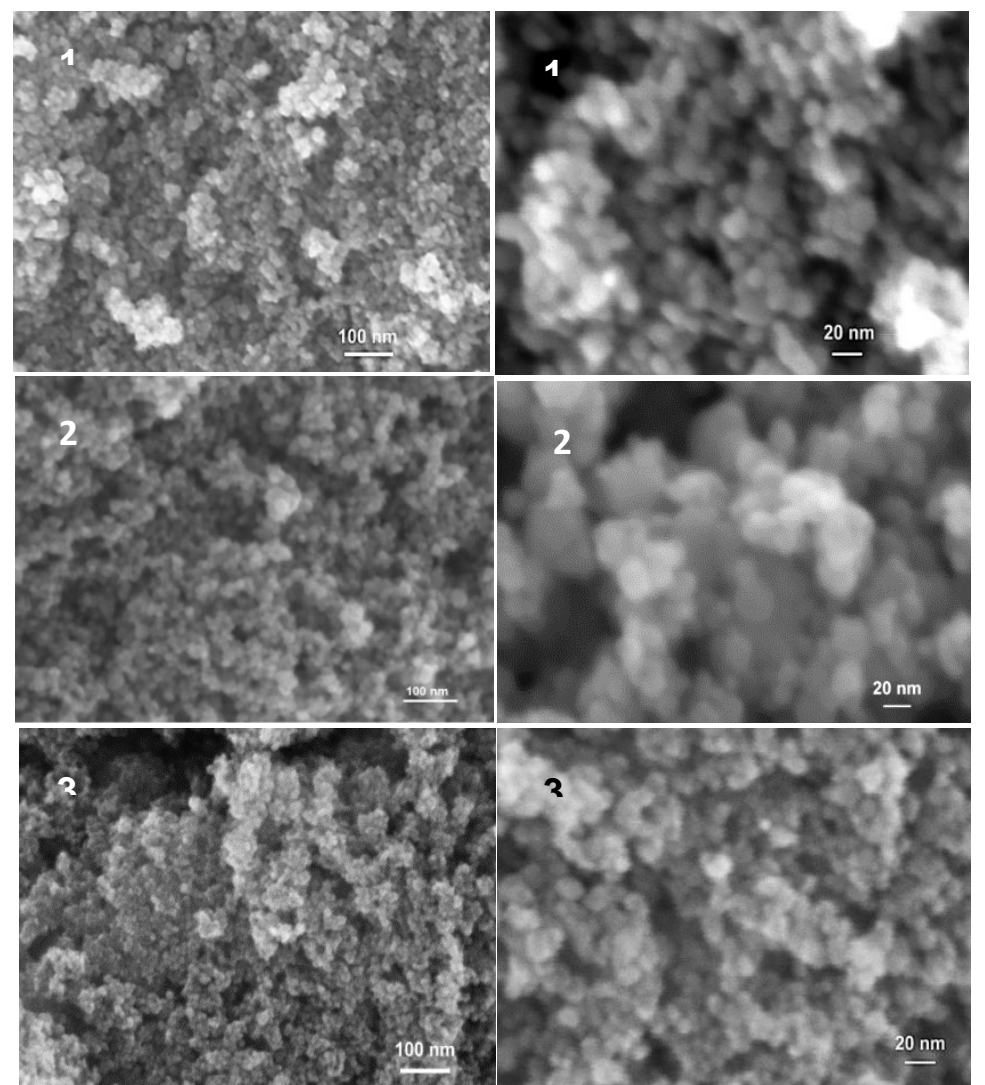

Figure 5. SEM image of the surface morphology of nanoparticles of powders obtained by techniques $1(\gamma-$ $\left.\mathrm{Fe}_{2} \mathrm{O}_{3}\right), 2\left(\gamma-\mathrm{Fe}_{2} \mathrm{O}_{3}-\mathrm{Fe}_{3} \mathrm{O}_{4}\right)$, and $3\left(\gamma-\mathrm{Fe}_{2} \mathrm{O}_{3}-\mathrm{Fe}_{3} \mathrm{O}_{4} @\right.$ oleic acid $)$.
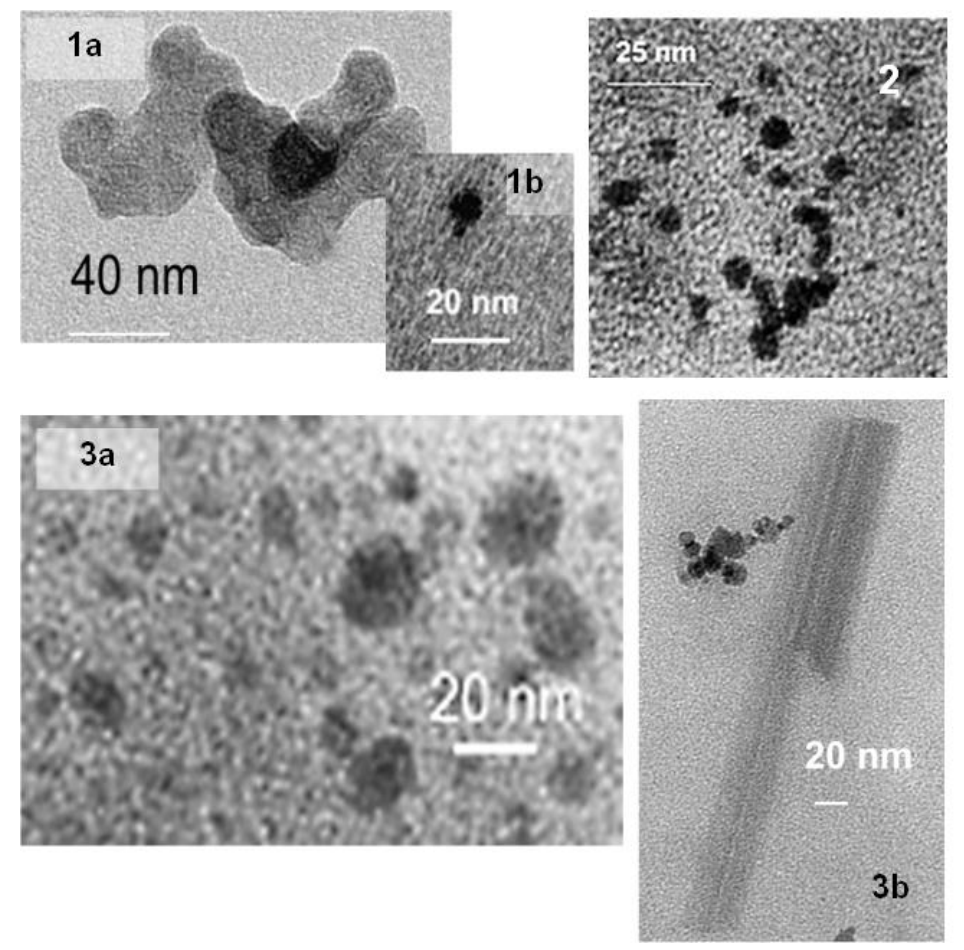

Figure 6. TEM images of iron oxide nanoparticles obtained:

- according to technique $1-\gamma-\mathrm{Fe}_{2} \mathrm{O}_{3}$, under ultrasonic action, with magnetic separation $(\mathbf{l a}, \mathbf{l b})$;

- according to technique $2-\gamma-\mathrm{Fe}_{2} \mathrm{O} 3-\mathrm{Fe}_{3} \mathrm{O}_{4}$, at $60{ }^{\circ} \mathrm{C}$ and bubbled with Ar, with magnetic separation (2);

- and according to technique $3-\gamma-\mathrm{Fe}_{2} \mathrm{O}_{3}-\mathrm{Fe}_{3} \mathrm{O}_{4} @$ oleic acid, at $60{ }^{\circ} \mathrm{C}$ and bubbled Ar, using oleic acid and the decantation method $(\mathbf{3 a}, \mathbf{3 b})$. 
It should be especially noted that large-sized lamellar nanoparticles tend to roll up into tubes. This can be seen from the TEM images (Fig. 6, 3 b), as well as from the microdiffraction pattern (Fig. 7 c). They are a two-dimensional thin object, lamellar, or rolled into a tube. This is evidenced by the characteristic bows, which are formed as a result of the fact that the invisible crystal planes become visible when tilted relative to the electron beam (Fig. 7c).
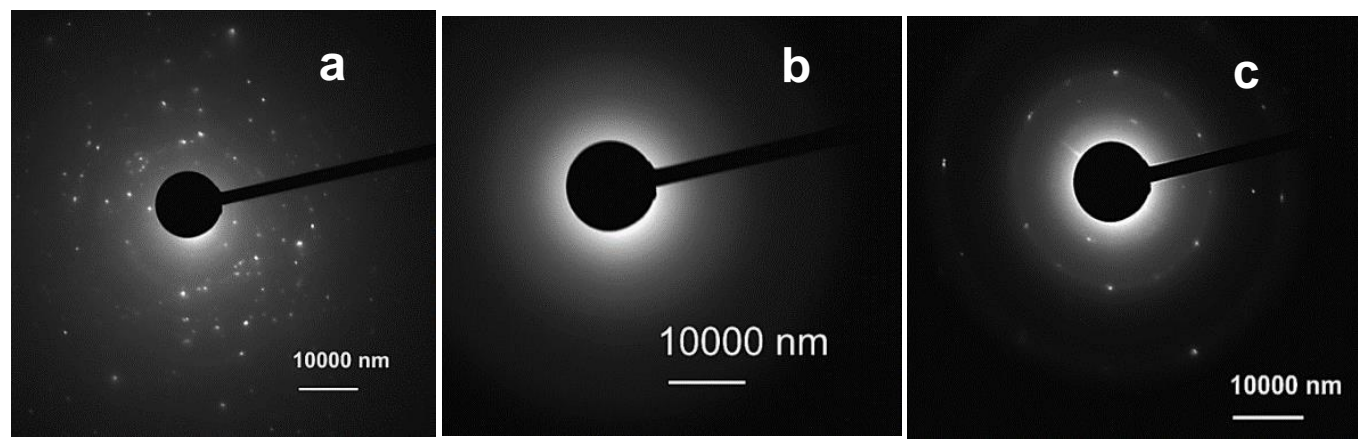

Figure 7. Microdiffraction patterns for nanopowders obtained by the following methods: $1-\gamma-\mathrm{Fe}_{2} \mathrm{O}_{3}(\mathbf{a}) ; 2-\gamma-$ $\mathrm{Fe}_{2} \mathrm{O}_{3}-\mathrm{Fe}_{3} \mathrm{O}_{4}(\mathbf{b})$, and $3-\gamma-\mathrm{Fe}_{2} \mathrm{O}_{3}-\mathrm{Fe}_{3} \mathrm{O}_{4} @$ oleic acid (c).

Polycrystalline nanopowders were obtained by all three methods as the diffraction patterns show thin rings (Fig. 7). For the $\gamma-\mathrm{Fe}_{2} \mathrm{O}_{3}$ nanopowder obtained by technique 1 , a chaotic distribution of luminous points is observed (Fig. 7a); that is, the structure of this nanopowder is less ordered. Thus, the deposition of nanoparticles with continuous bubbling with argon and heating to $60{ }^{\circ} \mathrm{C}$ promotes the formation of nanoparticles with a more ordered crystal structure.

Fig. 8a shows the complete nitrogen adsorption-desorption isotherms for iron oxide nanopowders obtained via techniques 1, 2, and 3, respectively. These isotherms are characterized by pronounced capillary-condensation hysteresis and belong to type IV according to the IUPAC classification, corresponding to adsorption on mesoporous (containing pores with a diameter of $2-50 \mathrm{~nm}$ ) materials. However, as can be seen from this figure, the shape of the hysteresis loops for nanopowders prepared by different methods differs significantly.
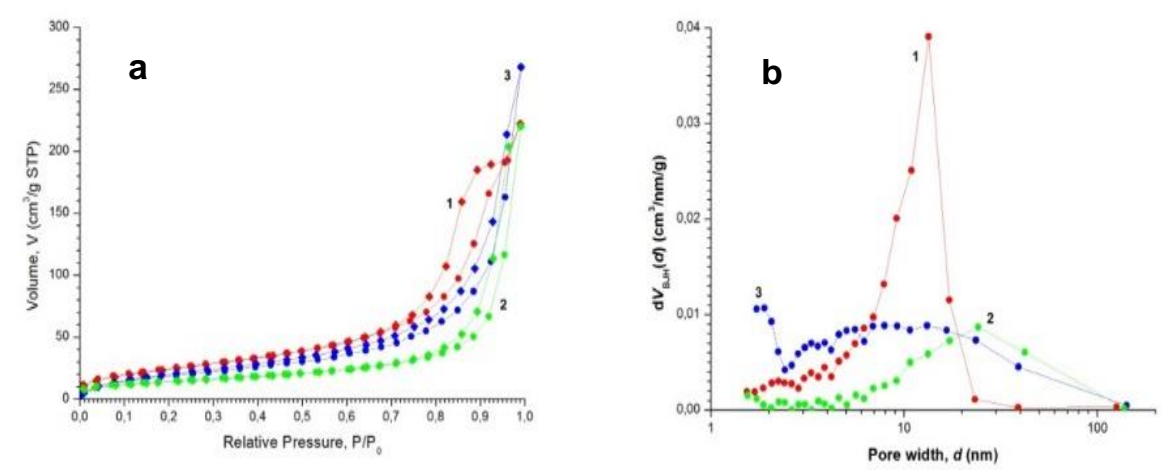

Figure 8. Adsorption-desorption isotherms (a) and their corresponding pore size distributions dV(D) (b), obtained from the analysis of desorption isotherms using the $\mathrm{BJH}$ model, for iron oxide nanopowders: (1) $\gamma$ $\mathrm{Fe}_{2} \mathrm{O}_{3}-1^{\text {st }}$ technique; (2) $\gamma-\mathrm{Fe}_{2} \mathrm{O}_{3}-\mathrm{Fe}_{3} \mathrm{O}_{4}-2^{\text {nd }}$ technique; (3) $\gamma-\mathrm{Fe}_{2} \mathrm{O}_{3}-\mathrm{Fe}_{3} \mathrm{O}_{4} @$ oleic acid $-3^{\text {nd }}$ technique.

Thus, the hysteresis loop observed for $\gamma-\mathrm{Fe}_{2} \mathrm{O}_{3}$ obtained by technique 1 almost completely corresponds to the classical type $\mathrm{H} 1$, which is characteristic of porous materials containing cylindrical pores open on both sides with a rather narrow pore size distribution. In this case, the fact that the closure of the adsorption and desorption branches occurs at the values 
of the partial pressures $\mathrm{P} / \mathrm{P}_{0}$, much higher than 0.3 , clearly indicates the absence of micropores in this sample.

In the case of nanopowders: $\gamma-\mathrm{Fe}_{2} \mathrm{O}_{3}-\mathrm{Fe}_{3} \mathrm{O}_{4}$ and $\gamma-\mathrm{Fe}_{2} \mathrm{O}_{3}-\mathrm{Fe}_{3} \mathrm{O}_{4} @$ oleic acid, prepared according to techniques 2 and 3, respectively, the shape of the hysteresis loops can be attributed to the $\mathrm{H} 3$ type according to the IUPAC classification, which is usually associated with the presence of slot-like pores characteristic for materials consisting of lamellar particles. Moreover, in the case of $\gamma-\mathrm{Fe}_{2} \mathrm{O}_{3}-\mathrm{Fe}_{3} \mathrm{O}_{4} @$ oleic acid nanopowder prepared by technique 3, the collapse of the hysteresis loop occurs at partial pressures $\mathrm{P} / \mathrm{P}_{0}<0.3$, which, in turn, indicates the presence of a significant number of micropores in the sample.

Mathematical processing of the complete nitrogen adsorption-desorption isotherms within the Barrett-Joyner-Halenda (BJH) model made it possible to obtain the pore size distributions dV(D) shown in Fig. 8b. As can be seen from this figure, the form of the obtained distributions $d V(D)$ significantly depends on the procedure for synthesizing the samples. Thus, for the $\gamma-\mathrm{Fe}_{2} \mathrm{O}_{3}$ nanopowder obtained by technique 1 , there is a clearly pronounced lognormal pore size distribution with a maximum in the mesopore region $d p \approx 13 \mathrm{~nm}$. At the same time, both micro- and macropores are practically absent in this sample. The pore size distribution $\mathrm{dV}(\mathrm{D})$ for the $\gamma-\mathrm{Fe}_{2} \mathrm{O}_{3}-\mathrm{Fe}_{3} \mathrm{O}_{4}$ composite nanopowder prepared according to technique 2 also has a lognormal form, but with a diffuse maximum shifted to the region of larger mesopores $d p \approx 24 \mathrm{~nm}$. There are no micropores in this sample (Fig. $8 \mathrm{~b}$ ), which is also evidenced by the closure of the hysteresis loop of adsorption-desorption isotherms in the region of high partial pressures. At the same time, for the composite $\gamma-\mathrm{Fe}_{2} \mathrm{O}_{3}-\mathrm{Fe}_{3} \mathrm{O}_{4} @$ oleic acid nanopowder prepared by technique 3 , the pore size distribution has a bimodal form with the maxima $\mathrm{dp} 1 \approx 2$ and $d p 2 \approx 8 \mathrm{~nm}$, respectively. Thus, the obtained distributions $d V(D)$ (Fig. $8 b$ ) are in satisfactory agreement with the conclusions drawn from the analysis of the shape of the total nitrogen adsorption-desorption isotherms for both iron oxide powders (Fig. 8a).

Table 2. The morphology of nanoparticles of powders obtained by three methods.

\begin{tabular}{|c|c|c|c|}
\hline Parameters & $\begin{array}{c}\text { 1 }^{\text {st }} \text { technique } \\
\gamma-\mathrm{Fe}_{2} \mathrm{O}_{3} \\
\end{array}$ & $\begin{array}{c}2^{\text {nd }} \text { technique } \\
\gamma-\mathrm{Fe}_{2} \mathrm{O}_{3}-\mathrm{Fe}_{3} \mathrm{O}_{4}\end{array}$ & $\begin{array}{c}3^{\text {nd }} \text { technique } \gamma \text {-Fe } \mathrm{Fe}_{2} \mathrm{O}_{3}-\mathrm{Fe}_{3} \mathrm{O}_{4} @ \text { oleic } \\
\text { acid }\end{array}$ \\
\hline $\mathrm{S}_{\mathrm{BET}}\left(\mathrm{m}^{2} / \mathrm{g}\right)$ & $92.0 \pm 4$ & $51.7 \pm 1$ & $75.0 \pm 11$ \\
\hline $\mathrm{V}_{\mathrm{P} / \mathrm{P} 0 \rightarrow 0.99}\left(\mathrm{~cm}^{3} / \mathrm{g}\right)$ & 0.35 & 0.34 & 0.43 \\
\hline $\mathrm{d}_{\mathrm{P}}(\mathrm{nm}) \mathrm{BJH}(\mathrm{des})$ & 13.4 & 24.2 & $1.9 ; 7.9$ \\
\hline $\begin{array}{l}\text { Pore and } \\
\text { nanoparticle type }\end{array}$ & $\begin{array}{l}\text { - open cylindrical } \\
\text { mesopores with a } \\
\text { narrow size } \\
\text { distribution; } \\
\text { - close to spherical } \\
\text { nanoparticles. }\end{array}$ & $\begin{array}{l}\text { - slit-like mesopores; } \\
\text { - lamellar nanoparticles. }\end{array}$ & $\begin{array}{l}\text { - slit-like micro- and mesopores; } \\
\text { - lamellar nanoparticles. }\end{array}$ \\
\hline $\begin{array}{l}\text { Nanoparticle size, } \\
\mathrm{nm}\end{array}$ & $\mathrm{d}=\sim 5-20(40)$ & $\delta=\sim 5-20$ & $\delta=\sim 10-20$ \\
\hline
\end{tabular}

Note: SBET - specific surface area; VP/P0 $\rightarrow 0.99$ - specific pore volume; dp - average pore diameter - parameters determined from the analysis of complete nitrogen adsorption-desorption isotherms using the BET and BJH models; $\mathrm{d}$ is the diameter for spherical nanoparticles or the size of lamellar nanoparticles (lamellar, determined from TEM data).

The results of determining the texture parameters of the iron oxide nanopowder samples obtained from the analysis of the complete nitrogen adsorption-desorption isotherms using the Brunauer-Emmett-Teller (BET) and BJH models are given in Table 2. According to the data obtained (see Table 2), $\gamma-\mathrm{Fe}_{2} \mathrm{O}_{3}$ nanopowder prepared under the ultrasonic treatment (technique 1) has the largest specific surface area $\left(\mathrm{SBET}=92 \mathrm{~m}^{2} / \mathrm{g}\right)$ and specific pore volume $(\mathrm{VP} / \mathrm{P} 0 \rightarrow$ $0.99=0.35 \mathrm{~cm}^{3} / \mathrm{g}$ ). The $\gamma-\mathrm{Fe}_{2} \mathrm{O}_{3}-\mathrm{Fe}_{3} \mathrm{O}_{4}$ sample obtained with argon bubbling and slight heating 
(technique 2) has a slightly lower specific surface area (SBET $=52 \mathrm{~m}^{2} / \mathrm{g}$ and almost the same specific pore volume $\left(\mathrm{VP} / \mathrm{P} 0 \rightarrow 0.99=0.34 \mathrm{~cm}^{3} / \mathrm{g}\right)$. The use of oleic acid as a surfactant leads to an increase in both the specific surface area $\left(\mathrm{SBET}=75 \mathrm{~m}^{2} / \mathrm{g}\right.$ ) and the specific pore volume $\left(\mathrm{VP} / \mathrm{P}_{0} \rightarrow 0.99=0.43 \mathrm{~cm}^{3} / \mathrm{g}\right)$ of $\gamma-\mathrm{Fe}_{2} \mathrm{O}_{3}-\mathrm{Fe}_{3} \mathrm{O}_{4} @$ oleic acid nanopowder (technique 3) compared with $\gamma-\mathrm{Fe}_{2} \mathrm{O}_{3}-\mathrm{Fe}_{3} \mathrm{O}_{4}$ nanopowder obtained under identical conditions (technique 2). The bimodal pore distribution in this powder may be due to the fact that it contains nanoparticles with a wide size distribution, both plate-like and rolled into a tube.

It should be noted separately that all three nanopowders obtained via the 1st, 2nd, and 3rd techniques have magnetic properties; they are attracted to the magnet. Powders $\gamma-\mathrm{Fe}_{2} \mathrm{O}_{3}$ and $\gamma-\mathrm{Fe}_{2} \mathrm{O}_{3}-\mathrm{Fe}_{3} \mathrm{O}_{4}$ were separated from the mother liquor by magnetic separation. Measurement of the magnetic properties of $\gamma-\mathrm{Fe}_{2} \mathrm{O}_{3}-\mathrm{Fe}_{3} \mathrm{O}_{4} @$ oleic acid powder using the NMR method in a flowing liquid (nutation method) [56] showed that this composite nanopowder is a soft magnetic material (saturation magnetization $20000 \mathrm{~A} / \mathrm{m}$, remanent magnetization 250 $\mathrm{A} / \mathrm{m}$, coercive force $370 \mathrm{~A} / \mathrm{m})$.

\subsection{Aggregate stability of aqueous suspensions of iron oxide nanopowders.}

Data on the change in the hydrodynamic diameter of iron oxide nanoparticles in aqueous suspensions during storage, which indirectly characterize the aggregate stability of these suspensions, is given in Table 3.

Table 3. Average value of the hydrodynamic diameter of iron oxide nanoparticles (D) was obtained by three different techniques in the supernatant liquids of aqueous suspensions during their storage.

\begin{tabular}{|c|c|c|c|}
\hline \multirow[t]{2}{*}{ Soak period } & \multicolumn{3}{|c|}{$\begin{array}{l}\text { Average value of the hydrodynamic diameter of iron oxide nanoparticles prepared } \\
\text { according to different aqueous synthesis techniques, D, nm }\end{array}$} \\
\hline & $\begin{array}{c}\mathbf{1}^{\text {st }} \text { variant } \\
\gamma-\mathrm{Fe}_{2} \mathrm{O}_{3}\end{array}$ & $\begin{array}{c}\mathbf{2}^{\text {nd }} \text { variant } \\
\gamma-\mathrm{Fe}_{2} \mathrm{O}_{3}-\mathrm{Fe}_{3} \mathrm{O}_{4}\end{array}$ & $\begin{array}{c}3^{\text {rd }} \text { variant } \\
\gamma-\mathrm{Fe}_{2} \mathrm{O}_{3}-\mathrm{Fe}_{3} \mathrm{O}_{4} @ \text { oleic acid }\end{array}$ \\
\hline \multicolumn{4}{|c|}{ The supernatant of the initial suspension $(0.1 \mathrm{~g} / \mathrm{L})$ after sonication $(240 \mathrm{~W}, 40 \mathrm{kHz}, 20$ minutes $)$ during storage } \\
\hline One week & 620 & 155 & 220 \\
\hline One month & 600 & 155 & 220 \\
\hline \multicolumn{4}{|c|}{ 10-Fold diluted supernatant of the original suspension during storage } \\
\hline One week & 600 & 145 & 180 \\
\hline One month & 650 & 140 & 180 \\
\hline Four months & - & 130 & 180 \\
\hline
\end{tabular}

As can be seen from the table, the size of the hydrodynamic diameter of $\gamma-\mathrm{Fe}_{2} \mathrm{O}_{3}$ nanoparticles without oleic acid is significantly larger (by 3 times) than for composite $\gamma-\mathrm{Fe}_{2} \mathrm{O}_{3}$ $\mathrm{Fe}_{3} \mathrm{O}_{4}$ and $\gamma-\mathrm{Fe}_{2} \mathrm{O}_{3}-\mathrm{Fe}_{3} \mathrm{O}_{4} @$ oleic acid nanoparticles, both with and without oleic acid. This can be caused by the larger size of $\gamma-\mathrm{Fe}_{2} \mathrm{O}_{3}$ nanoparticles, their greater tendency to aggregation, as well as the formation of a substantially thicker hydration shell (by a factor of 3 or more). Perhaps this is due to the presence of open cylindrical pores and a more developed surface. It can be noted that judging by the values of the hydrodynamic diameter, the size of iron oxide nanoparticles obtained by all three methods remained unchanged in aqueous suspensions for a rather long time - for 1 month, and for $\gamma-\mathrm{Fe}_{2} \mathrm{O}_{3}-\mathrm{Fe}_{3} \mathrm{O}_{4}$ and $\gamma-\mathrm{Fe}_{2} \mathrm{O}_{3}-\mathrm{Fe}_{3} \mathrm{O}_{4} @$ oleic acid nanoparticles - over 4 months.

The disadvantage of suspensions based on nanoparticles with oleic acid $\gamma-\mathrm{Fe}_{2} \mathrm{O}_{3}$ $\mathrm{Fe}_{3} \mathrm{O}_{4} @$ oleic acid is the difficulty of their preparation because the surface of the particles is poorly wetted with water. This problem was solved only with the use of ultrasonic exposure.

Thus, regardless of the specific features of the water deposition technique, iron oxide nanopowders corresponding to the phase composition of $\gamma-\mathrm{Fe}_{2} \mathrm{O}_{3}-\mathrm{Fe}_{3} \mathrm{O}_{4}$ solid solutions, both with and without surfactant on the surface, form stable aqueous suspensions with hydrated 
nanoparticle sizes in the range of $\sim 130-650 \mathrm{~nm}$. This conclusion is especially important since it is these hydrated nanoparticles that will subsequently interact with seeds or various parts of vegetative plants.

3.4. Biological activity of magnetic iron oxide nanoparticles and their effect on phytotest objects.

3.4.1. Fungicidal and bactericidal properties against fungal and bacterial phytopathogenic microorganisms.

Comparative assessment for the growth characteristics of bacterial colonies Xanthomonas campestris pv. campestris (Pammel) Dowson., strain 5212 - the causative agent of cabbage vascular bacteriosis, as well as spore germination and mycelium growth, the formation of colonies of fungus Cochliobolus sativus (S. Ito \& Kurib.) Drechsler ex Dastur the causative agent of barley dark brown spot and root rot for 5 days indicate that studied aqueous suspensions of $\gamma-\mathrm{Fe}_{2} \mathrm{O}_{3}$ nanoparticles $(0.001 ; 0.01 ; 0.1 ; 1.0 ; 10.0,100.0 \mathrm{mg} / \mathrm{L}), \gamma-$ $\mathrm{Fe}_{2} \mathrm{O}_{3}-\mathrm{Fe}_{3} \mathrm{O}_{4}$ and $\gamma-\mathrm{Fe}_{2} \mathrm{O}_{3}-\mathrm{Fe}_{3} \mathrm{O}_{4} @$ oleic acid nanoparticles $\left.(0.1 ; 1.0 ; 10.0 ; 100.0 \mathrm{mg} / \mathrm{L})\right)$, in the tested concentrations, do not possess fungicidal and bactericidal properties. In all variants of the experiment, the growth and development of pathogens did not differ from those in the control variants without the tested substances.

3.4.2. The effect of test crops seed treatment with magnetic iron oxide nanoparticles on plant resistance to damage by major phytopathogenic microorganisms.

The data obtained (Table 4) on the survival rate of white cabbage variety Penca de Povoa (k-2558, Portugal) plants and the incidence of blackleg disease when grown on a substrate infected with fungal phytopathogens of this disease, in a greenhouse complex, indicate that a weak protective effect on the plant, providing a tendency to an increase in their survival rate and a decrease in the damage score, is provided by aqueous suspensions of $\gamma$ $\mathrm{Fe}_{2} \mathrm{O}_{3}-\mathrm{Fe}_{3} \mathrm{O}_{4}$ nanoparticles at concentrations of 0.1 and $10.0 \mathrm{mg} / \mathrm{L}$ with the most pronounced positive effect at a lower suspension concentration; and $\gamma-\mathrm{Fe}_{2} \mathrm{O}_{3}-\mathrm{Fe}_{3} \mathrm{O}_{4} @$ oleic acid nanoparticles at a concentration of $1.0 \mathrm{mg} / \mathrm{L}$, which only at the indicated concentration showed a slightly more significant positive effect on plant stress resistance compared to that of a suspension of $\gamma-\mathrm{Fe}_{2} \mathrm{O}_{3}-\mathrm{Fe}_{3} \mathrm{O}_{4}$ nanoparticles without oleic acid at a concentration of $1.0 \mathrm{mg} / \mathrm{L}$. In other variants of concentrations, the protective effect was not revealed.

It should be noted that aqueous suspensions of $\gamma$ - $\mathrm{Fe}_{2} \mathrm{O}_{3}$ nanoparticles do not have a protective effect on plants due to the suppression of the vital activity of the latter. This effect is less pronounced at the lowest tested concentration of the $\gamma-\mathrm{Fe}_{2} \mathrm{O}_{3}$ nanoparticle suspension $(0.01 \mathrm{mg} / \mathrm{L})$ and increases with its raising.

Thus, suspensions of nanoparticles containing ferric and bivalent iron oxides $\left(\gamma-\mathrm{Fe}_{2} \mathrm{O}_{3}-\right.$ $\mathrm{Fe}_{3} \mathrm{O}_{4}$ ) were found to be more effective at low concentrations in increasing the resistance of white cabbage variety Penca de Povoa (k-2558, Portugal) plants to phytopathogenic damage compared to the suspensions of nanoparticles with ferric iron oxides $\left(\gamma-\mathrm{Fe}_{2} \mathrm{O}_{3}\right)$, which did not show a protective effect at the tested concentrations. The presence of the oleic acid shell on the surface of iron oxides $\left(\gamma-\mathrm{Fe}_{2} \mathrm{O}_{3}-\mathrm{Fe}_{3} \mathrm{O}_{4} @\right.$ oleic acid) magnetic nanoparticles also mainly did not have a significant positive effect on their phytoprotective ability under conditions of infection with fungal pathogens that cause blackleg in cabbage crops. 
Table 4. Survival of white cabbage variety Penca de Povoa (k-2558, Portugal) plants and its susceptibility to blackleg when grown from seeds treated with the studied substances in favorable concentrations for plants, in a substrate infected with fungal pathogens of root rot

\begin{tabular}{l|c|c} 
Seed treatment option & $\begin{array}{c}\% \text { alive } \\
\text { plants }\end{array}$ & $\begin{array}{c}\text { Weighted average } \\
\text { damage score }\end{array}$ \\
\hline water is a sterile substrate (control) & 100,00 & 1 \\
\hline $0.1 \mathrm{mg} / \mathrm{L} \gamma-\mathrm{Fe}_{2} \mathrm{O}_{3}-\mathrm{Fe}_{3} \mathrm{O}_{4}$ & 57.15 & 4 \\
\hline $10.0 \mathrm{mg} / \mathrm{L} \gamma-\mathrm{Fe}_{2} \mathrm{O}_{3}-\mathrm{Fe}_{3} \mathrm{O}_{4}$ & 45.72 & 5 \\
\hline $1.0 \mathrm{mg} / \mathrm{L} \gamma-\mathrm{Fe}_{2} \mathrm{O}_{3}-\mathrm{Fe}_{3} \mathrm{O}_{4}$ - oleic acid & 45.72 & 5 \\
\hline $1.0 \mathrm{mg} / \mathrm{L} \gamma-\mathrm{Fe}_{2} \mathrm{O}_{3}-\mathrm{Fe}_{3} \mathrm{O}_{4}$ & 34.29 & 7 \\
\hline $0.01 \mathrm{mg} / \mathrm{L} \gamma-\mathrm{Fe}_{2} \mathrm{O}_{3}$ & 22.86 & 7 \\
\hline water & 38,86 & 8 \\
\hline $0.1 \mathrm{mg} / \mathrm{L} \gamma-\mathrm{Fe}_{2} \mathrm{O}_{3}$ & 0.00 & 9 \\
\hline $1.0 \mathrm{mg} / \mathrm{L} \gamma-\mathrm{Fe}_{2} \mathrm{O}_{3}$ & 0.00 & 9 \\
\hline $0.1 \mathrm{mg} / \mathrm{L} \gamma-\mathrm{Fe}_{2} \mathrm{O}_{3}-\mathrm{Fe}_{3} \mathrm{O}_{4}$ @ oleic acid & 0.00 & 9 \\
\hline $10.0 \mathrm{mg} / \mathrm{L} \gamma-\mathrm{Fe}_{2} \mathrm{O}_{3}$ & 0.00 & 9 \\
\hline $10.0 \mathrm{mg} / \mathrm{L} \gamma-\mathrm{Fe}_{2} \mathrm{O}_{3}-\mathrm{Fe}_{3} \mathrm{O}_{4}$ - @oleic acid & 0.00 & 9
\end{tabular}

3.4.3. Influence of the iron oxides magnetic nanoparticles concentrations on plant germination and morphometric characteristics.

A series of experiments revealed similarities and differences in the reaction of plants: spring barley variety Leningradsky, white cabbage variety Penca de Povoa, k-2558 and cauliflower variety Hobart, k-874, as well as watercress variety Azhur for presowing seed treatment with aqueous suspensions of iron oxides magnetic nanoparticles in the concentration range $0.00001-100.0 \mathrm{mg} / \mathrm{L}$ (Electronic supplementary information, Table 1-3).

Various plant sensitivity to the effect of $\gamma-\mathrm{Fe}_{2} \mathrm{O}_{3}$ nanoparticles in the tested concentration ranges revealed (Electronic supplementary information, Table 1). Thus, the watercress of the Azhur variety and the white cabbage of variety the Penca de Povoa at the initial stages of germination turned out to be indifferent to the treatment of seeds with $\gamma-\mathrm{Fe}_{2} \mathrm{O}_{3}$ suspensions, judging by the absence of the change in the indices of their germination energy and germination capacity. At the same time, cauliflower variety Hobart, k-874, and spring barley variety Leningradskiy reacted to seed treatment with $\gamma-\mathrm{Fe}_{2} \mathrm{O}_{3}$ suspensions at concentrations $(0.001,0.1,1.0,10) \mathrm{mg} / \mathrm{L}$ and $(0.0001,0.01,100.0) \mathrm{mg} / \mathrm{L}$, respectively, slowing germination on the $3 \mathrm{rd}$ day. On the 7 th day, the marked inhibiting effect was retained in cauliflower in the variants of seed treatment with $\gamma-\mathrm{Fe}_{2} \mathrm{O}_{3}$ suspensions $(0.1 \mathrm{mg} / \mathrm{L})$, and in spring barley - at 0.01 and $100.0 \mathrm{mg} / \mathrm{L}$.

Differences in the direction of changes in the values of germination energy in different crops after treatment of their seeds with a suspension of $\gamma-\mathrm{Fe}_{2} \mathrm{O}_{3}-\mathrm{Fe}_{3} \mathrm{O}_{4}$ nanoparticles relative to those in control were manifested from a pronounced decrease in spring barley, a neutral reaction - in white cabbage, and stimulation in the form of a trend or significant - in cauliflower. (Electronic supplementary information, Table 2). Seed germination in all crops mainly did not differ from that in control or was higher, as, for example, in spring barley in the variants of seed treatment with suspensions of $\gamma-\mathrm{Fe}_{2} \mathrm{O}_{3}-\mathrm{Fe}_{3} \mathrm{O}_{4}$ nanoparticles at concentrations of $0.01,1$, and $10 \mathrm{mg} / \mathrm{L}$. An exception was the treatment of barley seeds with a suspension of $\gamma-\mathrm{Fe}_{2} \mathrm{O}_{3}-$ $\mathrm{Fe}_{3} \mathrm{O}_{4}$ nanoparticles at a maximum concentration of $100 \mathrm{mg} / \mathrm{L}$, which showed an inhibitory effect on this indicator.

The presence of the oleic acid shell on the surface of $\gamma-\mathrm{Fe}_{2} \mathrm{O}_{3}-\mathrm{Fe}_{3} \mathrm{O}_{4} @$ oleic acid nanoparticles, when treated with suspensions of Leningradskiy spring barley seeds at a concentration of $0.0001 \mathrm{mg} / \mathrm{L}$, did not affect the germination energy of seeds; at a concentration of $0.01 \mathrm{mg} / \mathrm{L}$ it significantly contributed to an increase in this value (by $24 \%$ ), and in other concentrations $(0.001 ; 0.1 ; 1.0 ; 10.0$ and $100.0 \mathrm{mg} / \mathrm{L})$, it mainly significantly or in the form of 
a tendency decreased its values relative to the control (Electronic supplementary information, Table 3). Treatment for seeds of white cabbage variety Penca de Povoa or cauliflower variety Hobart with the above-mentioned suspensions of $\gamma-\mathrm{Fe}_{2} \mathrm{O}_{3}-\mathrm{Fe}_{3} \mathrm{O}_{4} @$ oleic acid nanoparticles mainly did not cause significant differences in the germination energy values from those in control, except for the treatment of cauliflower seeds at a concentration of $0,01 \mathrm{mg} / \mathrm{L}$. All the differences revealed at the initial stages of germinations were leveled out on the 7 th day, and in terms of germination, the experimental variants did not differ significantly from the control ones in all three phyto test cultures. A pronounced tendency to stimulate the germination of spring barley seeds in the variants of their treatment with suspensions of $\gamma-\mathrm{Fe}_{2} \mathrm{O}_{3}-\mathrm{Fe}_{3} \mathrm{O}_{4} @$ oleic acid at concentrations of 0.001 and $0.01 \mathrm{mg} / \mathrm{L}$ can be noted.

Judging by all the assessed growth and development indices of plant seedlings, the treatment of their seeds with $\gamma-\mathrm{Fe}_{2} \mathrm{O}_{3}$ suspensions had no effect or contributed to a significant increase or in the form of a weak tendency, by 3-15\% in the length of the sprouts of garden cress variety Azhur at concentrations of 0.0001, 0.001, 0.01, 0.1, 1.0 and $10.0 \mathrm{mg} / \mathrm{L}$; spring barley variety the Leningradskiy - in concentrations of 0.1 and $1.0 \mathrm{mg} / \mathrm{L}$, white cabbage - in concentrations of $0.00001,0.0001,0.01 ; 1.0,10.0$ and $100.0 \mathrm{mg} / \mathrm{L}$. cauliflower - at a concentration of $0.00001,0.0001,0.001,0.01,0.1 \mathrm{mg} / \mathrm{L}$. At the same time, there is a weak or pronounced stimulation of root growth in garden cress by 6-28\% with an increase in the manifestation of the effect in the variants of seed treatment with $\gamma-\mathrm{Fe}_{2} \mathrm{O}_{3}$ suspensions at low concentrations $(0.001$ and $0.01 \mathrm{mg} / \mathrm{L})$; in spring barley - in concentrations of $0.0001,0.01$ and $0.1 \mathrm{mg} / \mathrm{L}$. It should be noted that there is a tendency towards a slowdown in root growth also in variants with seed treatment with $\gamma-\mathrm{Fe}_{2} \mathrm{O}_{3}$ suspensions at concentrations: for barley -0.001 , 10 and $100 \mathrm{mg} / \mathrm{L}$; for white cabbage $-0.01-100 \mathrm{mg} / \mathrm{L}$; for cauliflower $-0.00001-1.0 \mathrm{mg} / \mathrm{L}$.

Treatment of test cultures seeds with suspensions of $\gamma-\mathrm{Fe}_{2} \mathrm{O}_{3}-\mathrm{Fe}_{3} \mathrm{O}_{4}$ nanoparticles in a wide range of concentrations also revealed differences in the response of plant cultures, namely: in cabbage crops - mainly stimulation of growth characteristics of plants (increase in the length of shoots and roots by 3-18\%); while in spring barley - a significant (in the variant with a concentration of $10 \mathrm{mg} / \mathrm{L}$ ) or in the form of a weak trend - a decrease in the growth rates of seedlings (by 5-14\%).

It was revealed that the presence of oleic acid shell on the surface of $\gamma-\mathrm{Fe}_{2} \mathrm{O}_{3}-$ $\mathrm{Fe}_{3} \mathrm{O}_{4} @$ oleic acid nanoparticles contributed to an increase (up to 34\%) in the absolute values of growth indicators of barley seedlings when compared with those in the variants with seed treatment with suspensions of $\gamma-\mathrm{Fe}_{2} \mathrm{O}_{3}-\mathrm{Fe}_{3} \mathrm{O}_{4}$ nanoparticles without oleic acid or $\gamma-\mathrm{Fe}_{2} \mathrm{O}_{3}$. At the same time, the treatment of white cabbage seeds with suspensions of $\gamma-\mathrm{Fe}_{2} \mathrm{O}_{3}-\mathrm{Fe}_{3} \mathrm{O}_{4} @$ oleic acid nanoparticles did not affect the growth of sprouts but somewhat inhibited the growth of roots. The effect of seed treatment with $\gamma-\mathrm{Fe}_{2} \mathrm{O}_{3}-\mathrm{Fe}_{3} \mathrm{O}_{4} @$ oleic acid suspensions on root growth, similar to the latter, was observed in cauliflower. However, in relation to sprouts, in contrast to that observed in white cabbage, stimulation of their growth (by 8-15\%) was revealed at low concentrations of $\gamma-\mathrm{Fe}_{2} \mathrm{O}_{3}-\mathrm{Fe}_{3} \mathrm{O}_{4}$ nanoparticles $(0.0001,0.001,0.01 \mathrm{mg} / \mathrm{L}$ ).

In general, judging by all the assessed growth and development indices of plant seedlings, the treatment of various plant species seeds with aqueous suspensions of $\gamma-\mathrm{Fe}_{2} \mathrm{O}_{3}$, $\gamma-\mathrm{Fe}_{2} \mathrm{O}_{3}-\mathrm{Fe}_{3} \mathrm{O}_{4}$, and $\gamma-\mathrm{Fe}_{2} \mathrm{O}_{3}-\mathrm{Fe}_{3} \mathrm{O}_{4} @$ oleic acid have a weak positive effect on plants in the concentration range $0.00001-1 \mathrm{mg} / \mathrm{L}$. The severity of the effect depends on the composition and concentration of the tested substance and is determined by the specific characteristics of the plant reaction. Thus, iron oxide nanoparticles in lower concentrations had a more significant 
positive effect on cabbage crops (white cabbage and cauliflower) relative to controls; no significant effect on the growth characteristics of nanoparticles was found on spring barley.

All the revealed differences in germination energy at the initial stages of plant development were leveled out on the 7th day, and in terms of germination, the experimental variants did not significantly differ from the control ones in all three phyto test cultures.

3.4.4. Determination of the ranges of created compounds concentrations with positive influence under vegetative plants foliar treatment.

Based on the results obtained on the treatment of plant seeds, a range of concentrations of aqueous suspensions of $\gamma-\mathrm{Fe}_{2} \mathrm{O}_{3}$ and $\gamma-\mathrm{Fe}_{2} \mathrm{O}_{3}-\mathrm{Fe}_{3} \mathrm{O}_{4} @$ oleic acid nanoparticles were selected - 0.001-1.0 mg/L for foliar treatment of cucumber and lettuce seedlings.

The results of studies of the effect of magnetic nanoparticles obtained by 2 techniques (1st and 3rd) on the morphophysiological characteristics of plants of the hybrid Neva F1 cucumber are shown in Fig. 9. It can be seen that practically all the assessed indicators of the physiological state of plants (height, number of leaves, moisture content of plant material, raw ash, and the above-mentioned weight of the above-ground part) have higher values compared to the control.
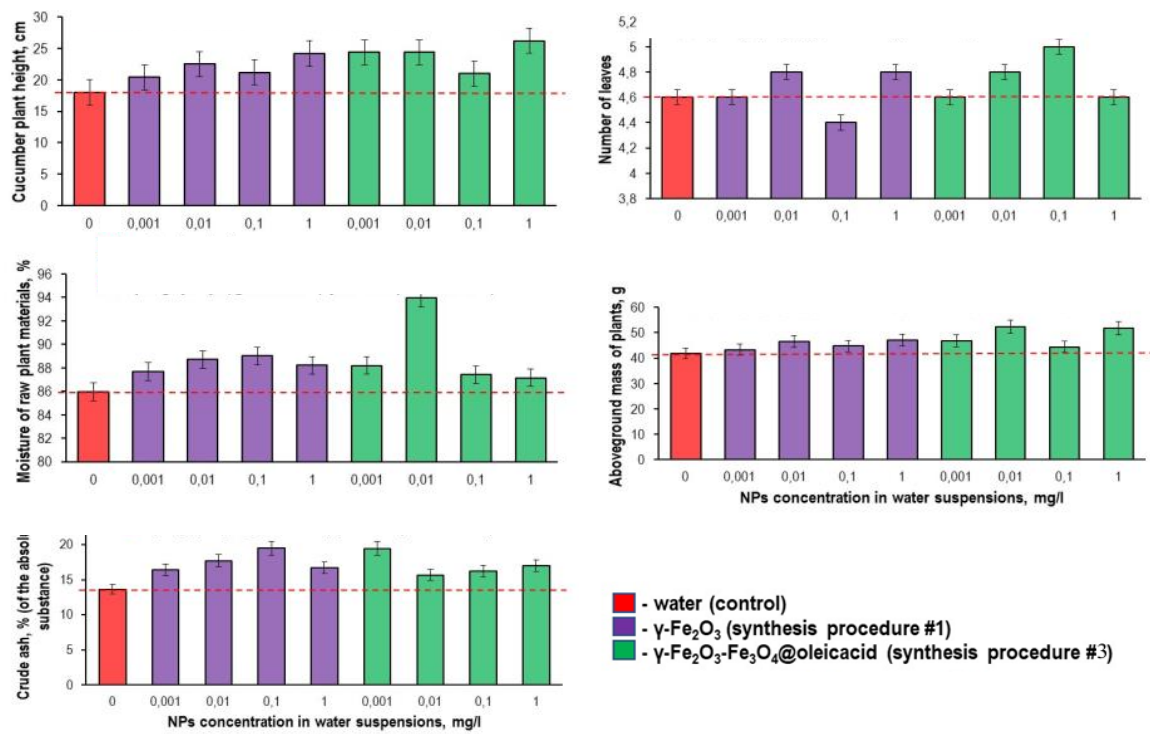

Figure 9. Morphophysiological parameters of cucumber plants after foliar treatment with aqueous suspensions of magnetic nanoparticles of iron oxides $\gamma-\mathrm{Fe}_{2} \mathrm{O}_{3}$ and $\gamma-\mathrm{Fe}_{2} \mathrm{O}_{3}-\mathrm{Fe}_{3} \mathrm{O}_{4} @$ oleic acid in various concentrations when growing plants under controlled conditions of intensive light culture.

Similar studies using only $\gamma-\mathrm{Fe}_{2} \mathrm{O}_{3}$ nanoparticles were repeated for two crops - a hybrid of cucumber Neva F1 and lettuce variety Typhoon (Electronic supplementary information, Tables $4 \& 5)$.

It was found that aqueous suspensions of $\gamma-\mathrm{Fe}_{2} \mathrm{O}_{3}$ nanopowder at the tested concentrations of 0.001-1.0 mg/L had a pronounced or weak tendency of stimulating effect on plant growth indicators under foliar treatment of the cucumber and lettuce plants during vegetative development (Electronic supplementary information, Table 4).

As our studies have shown, the stimulation of the cucumber and lettuce plants growth under the influence of the synthesized magnetic iron oxide nanopowder is mainly due to: (a) an increase in the intake of mineral nutrients, including zinc, manganese, into the above-ground 
part of the treated plants, which can be judged by a significant increase in the content raw plant ash and the content of these elements (Electronic supplementary information, Table 5); (b) a pronounced tendency to an increase in the water content of the tissues of stems and leaves after treatment with suspensions of iron oxide, which in turn indirectly indicates a higher osmotic potential in them due to the accumulation of low molecular weight compounds; to study the noted effect, it is planned to carry out further experiments on the effect of magnetic iron oxide nanoparticles suspensions under soil drought conditions on the stress resistance of plants; (c) an increase in the area of the assimilating leaf surface and the content of chlorophylls in plant leaves. The latter is more pronounced in the variants with the plants treated with $\gamma-\mathrm{Fe}_{2} \mathrm{O}_{3}$ suspensions at concentrations of 0.01 and $0.001 \mathrm{mg} / \mathrm{L}$ (Electronic supplementary information, Table 5). In variants with a higher concentration, the content of chlorophylls in the leaves does not differ from that in control. It should be noted that there are differences in the direction of changes in the carotenoids content in cucumber and lettuce plants after treatment with suspensions of iron oxide at various concentrations. Thus, in cucumber leaves, it is similar to that in chlorophylls with maximum values when exposed to $\gamma-\mathrm{Fe}_{2} \mathrm{O}_{3}$ nanoparticles in low concentrations and their decrease at concentrations of 0.1 and $1.0 \mathrm{mg} / \mathrm{L}$, although more significant relative to the control (by 18\%). In lettuce leaves, under the influence of treatment with $\gamma-\mathrm{Fe}_{2} \mathrm{O}_{3}$ suspensions, a significant or tendency reduction in the content of carotenoids by $13-28 \%$ is noted in the entire range of tested concentrations. It is well known that chlorophylls $\mathrm{a}$ and $\mathrm{b}$, carotenoids are pigments involved in photosynthesis and / or redox processes, and the trace element iron catalyzes the formation of chlorophyll a pigment precursors - aminolevulinic acid and protoporphyrins. In addition, iron compounds are involved in the formation of chloroplast components: cytochromes, ferredoxin, etc. Apparently, with an increase in the concentration of suspensions of iron nanoparticles during plant foliar treatment, the need for the synthesis of secondary metabolites, including a number of pigments that enhance the absorption of this microelement by the root system, decreases. The revealed phenomenon requires additional in-depth research.

The revealed pronounced positive effect of foliar treatment with aqueous suspensions of nanoparticles on the cucumber plants rates (F1 Neva hybrid) growth, the processes of the biosynthesis of photosynthetic pigments in the leaves, the enrichment of nutrients in the aboveground part of plants in the complex, obviously, provided the manifestation of a weak tendency of plants productivity increase in variants treatment of plants with nanoparticles at a concentration of $0.01 \mathrm{mg} / \mathrm{L}$ (Table 5).

Thus, the observed stimulation of the cucumber and lettuce seedlings growth after foliar treatment with aqueous suspensions of magnetic iron oxide nanopowder (maghemite) is mainly due to the intensification of metabolic processes and the supply of nutrients necessary for plants to the above-ground part.

Table 5. Influence of foliar treatment with suspensions of iron oxide nanoparticles (concentration $0.01 \mathrm{mg} / \mathrm{L}$ ) on the productivity of cucumber plants (for example, F1 Neva hybrid) when grown under controlled conditions of intensive light culture.

\begin{tabular}{|c|c|c|c|c|c|c|}
\hline \multirow{2}{*}{ Foliage Reagents } & \multicolumn{2}{|c|}{ Number of fruits } & \multicolumn{2}{|c|}{ Weight of one fruit } & \multicolumn{2}{|c|}{ Yield, kg of fruits per $\mathbf{m}^{2}$} \\
\hline & amount & $\%$ of control & $\mathrm{g}$ & $\%$ of control & $\mathrm{kg}$ & $\%$ of control \\
\hline Water (control) & $12.5 \pm 1.2$ & 100 & $19.0 \pm 4.7$ & 100 & $19.4 \pm 1.9$ & 100 \\
\hline$\gamma-\mathrm{Fe}_{2} \mathrm{O}_{3}$ & $13.0 \pm 2.5$ & 104 & $19.5 \pm 8.7$ & 99 & $20.0 \pm 2.7$ & 103 \\
\hline$\gamma-\mathrm{Fe}_{2} \mathrm{O}_{3}-\mathrm{Fe}_{3} \mathrm{O}_{4}$ & $13.0 \pm 0.7$ & 104 & $18.5 \pm 1.2$ & 98 & $19.7 \pm 1.6$ & 102 \\
\hline$\gamma-\mathrm{Fe}_{2} \mathrm{O}_{3}-\mathrm{Fe}_{3} \mathrm{O}_{4} @$ oleic acid & $13.5 \pm 1.2$ & 108 & $202.5 \pm 8.5$ & 104 & $21.9 \pm 3.6$ & 113 \\
\hline
\end{tabular}


An increase in nutrition and an increase in the content of mineral elements in plants contribute to an increase in the osmotic potential and, as a consequence, the hydration of tissues due to the flow of water into cells with increased osmotic potential. This is a very positive fact, which may indicate the ability of magnetic iron oxide nanoparticles to increase the plant's resistance in drought conditions. It is obvious that iron, as a cofactor of many enzymes, is involved in many metabolic processes in plants. Therefore, further study of the mechanisms of the influence of magnetic nanoparticles of iron oxides of various crystalline modifications is of great interest. The data obtained indicate that further studies of the mechanisms of the influence of magnetic nanoparticles of iron oxides on plants under favorable and stressful conditions are promising in order to create highly effective nano preparation and technology for their use in crop production of an open and protected ground, aimed at increasing the resistance of plants to stress factors and increasing the efficiency of their production potential.

\section{Conclusions}

Three variants of magnetic nanoparticles of iron oxides, differing in phase composition, shape, and texture, were obtained by chemical deposition from aqueous solutions of iron (II, III) chlorides. The synthesis procedure was distinguished by the fact that according to the $1 \mathrm{st}$ technique, ultrasonication was used, according to the 2nd technique - bubbling with argon and heating to $60{ }^{\circ} \mathrm{C}$ during deposition, according to the $3 \mathrm{rd}$ technique, the synthesis was carried out similar to the second variant. Additionally, oleic acid was introduced into the reaction mixture. The mixture was subjected to homogenization at $50{ }^{\circ} \mathrm{C}$ and separated from the mother liquor not by magnetic separation (as in the first two variants), but by decantation. As a result, nanoparticles obtained under ultrasonication at room temperature most closely correspond in phase composition to maghemite $\left(\gamma-\mathrm{Fe}_{2} \mathrm{O}_{3}\right)$, the shape of them is close to spherical and size within 5-20 (up to $\sim 40 \mathrm{~nm}$ ), with a specific surface area of $\sim 92 \mathrm{~m}^{2} / \mathrm{g}$. According to the second and third techniques of synthesis, with bubbling with argon and slight heating $\left(60{ }^{\circ} \mathrm{C}\right)$, regardless of the method of isolation from the mother liquor and the presence or absence of a shell of oleic acid, identical in phase composition lamellar nanoparticles were obtained, which corresponds to a solid solution of maghemite-magnetite $\gamma-\mathrm{Fe}_{2} \mathrm{O}_{3}-\mathrm{Fe}_{3} \mathrm{O}_{4}$. Thus, according to the second and third techniques, nanoparticles of iron oxides with a higher content of ferrous iron were obtained in comparison with the nanoparticles obtained by the first method. As a result of the introduction of oleic acid into the reaction mixture, a film was formed on the surface of the nanoparticles, and composite $\gamma-\mathrm{Fe}_{2} \mathrm{O}_{3}-\mathrm{Fe}_{3} \mathrm{O}_{4} @$ oleic acid nanoparticles were formed. This somewhat increased both the size of nanoparticles (from $\sim 5-20 \mathrm{~nm}$ to $\sim 10-20$ and even up to $\sim 40 \mathrm{~nm}$ ) and the specific surface area (from $\sim 52$ to $75 \mathrm{~m}^{2} / \mathrm{g}$ ). At the same time, individual composite lamellar nanoparticles tended to roll up into tubes. After reaching sedimentation stability, aqueous suspensions of all three variants of nanoparticles retained their aggregate stability for more than 1 month at an aggregate size of $\sim 550 \mathrm{~nm}$ (for $\gamma-\mathrm{Fe}_{2} \mathrm{O}_{3}$ ) and for more than 4 months at an aggregate size of $\sim 130 \mathrm{~nm}$ (for $\gamma-\mathrm{Fe}_{2} \mathrm{O}_{3}-\mathrm{Fe}_{3} \mathrm{O}_{4}$ ) and $\sim 180 \mathrm{~nm}$ (for $\gamma-\mathrm{Fe}_{2} \mathrm{O}_{3}-$ $\mathrm{Fe}_{3} \mathrm{O}_{4} @$ oleic acid).

The studied aqueous suspensions of $\gamma-\mathrm{Fe}_{2} \mathrm{O}_{3}$ nanoparticles $(0.001 ; 0.01 ; 0.1 ; 1.0 ; 10.0$, $100.0 \mathrm{mg} / \mathrm{L}$ ), and $\gamma-\mathrm{Fe}_{2} \mathrm{O}_{3}-\mathrm{Fe}_{3} \mathrm{O}_{4}$ and $\gamma-\mathrm{Fe}_{2} \mathrm{O}_{3}-\mathrm{Fe}_{3} \mathrm{O}_{4} @$ oleic acid nanoparticles $(0.1 ; 1.0 ; 10.0$; $100.0 \mathrm{mg} / \mathrm{L}$ ), in the tested concentrations do not possess fungicidal and bactericidal properties in relation to phytopathogens - the causative agent of dark brown spot and root rot of barley the micromycete Cochliobolus sativus (S. Ito \& Kurib.) and the causative agent of vascular 
bacteriosis of cabbage - Xanthomonas campestris pv. campestris (Pammel) Dowson, respectively.

Aqueous suspensions of magnetic nanoparticles corresponding to the composition of the $\gamma-\mathrm{Fe}_{2} \mathrm{O}_{3}-\mathrm{Fe}_{3} \mathrm{O}_{4}$ solid solution, containing oxides of ferric and ferrous iron, were found to be more effective at low concentrations in increasing the resistance of white cabbage cultivar Penca de Povoa (k-2558, Portugal) plants to fungal pathogens causing blackleg in cabbage crops, compared with suspensions of nanoparticles that most closely correspond to the composition of maghemite $\left(\gamma-\mathrm{Fe}_{2} \mathrm{O}_{3}\right)$, which did not show a protective effect at the tested concentrations. The presence of a shell of oleic acid on the surface of magnetic nanoparticles of iron oxides $\left(\gamma-\mathrm{Fe}_{2} \mathrm{O}_{3}-\mathrm{Fe}_{3} \mathrm{O}_{4}\right)$ also predominantly did not have a significant positive effect on their phytoprotective ability in conditions of infection with phytopathogens causing blackleg disease. On the contrary, smaller, also lamellar nanoparticles 5-20 nm in size, corresponding to the composition of the $\gamma-\mathrm{Fe}_{2} \mathrm{O}_{3}-\mathrm{Fe}_{3} \mathrm{O}_{4}$ solid solution, without oleic acid, exhibited higher protective properties. In the future, it is of interest to find out what affects to a greater extent the bactericidal properties of nanoparticles - their size or phase composition (Fe atoms in oxidation state II or III).

In general, judging by all the assessed growth and development indices of plant seedlings, the treatment of seeds of various plant species with aqueous suspensions of $\gamma-\mathrm{Fe}_{2} \mathrm{O}_{3}$, $\gamma-\mathrm{Fe}_{2} \mathrm{O}_{3}-\mathrm{Fe}_{3} \mathrm{O}_{4}$, and $\gamma-\mathrm{Fe}_{2} \mathrm{O}_{3}-\mathrm{Fe}_{3} \mathrm{O}_{4} @$ oleic acid nanoparticles have a weak positive effect on plants in the concentration range $0.00001-1 \mathrm{mg} / \mathrm{L}$. The severity of the effect depends on the composition and concentration of the tested substance and is determined by the specific characteristics of the plant reaction. Thus, iron oxide nanoparticles in lower concentrations had a more significant positive effect on cabbage crops (white cabbage and cauliflower) relative to the control. No significant effect on the growth characteristics of spring barley was found. All the revealed differences in germination energy at the initial stages of plant development were leveled significantly from the control in all three phyto test cultures. The stimulation of the growth of seedlings of cucumber and lettuce after foliar treatment with aqueous suspensions of magnetic $\gamma-\mathrm{Fe}_{2} \mathrm{O}_{3}$ nanoparticles, revealed in a series of vegetation experiments under controlled conditions of intensive light culture, is mainly due to an increase in metabolic processes and the supply of nutrients necessary for plants to the above-ground part. An increase in nutrition and an increase in the content of mineral elements in plants contributes to an increase in the osmotic potential and, as a consequence, tissue hydration due to the flow of water into cells with increased osmotic potential. This is a very positive fact, which may indicate the ability of magnetic iron oxide nanoparticles to increase the resistance of plants in drought conditions. It is obvious that iron, as a cofactor of many enzymes, is involved in many metabolic processes in plants. Therefore, further study of the mechanisms of the influence of magnetic nanoparticles of iron oxides in various crystalline modifications is of great interest. The data obtained indicate that further studies of the mechanisms of the influence of magnetic nanoparticles of iron oxides on plants under favorable and stressful conditions are promising in order to create highly effective nano preparation and technology for their use in crop production of open and protected ground, aimed at increasing the resistance of plants to stress factors and increasing the efficiency of their production potential.

In general, the phase composition and size of nanoparticles obtained by all three methods are close. However, even a small shift towards an increase in the number of ferrous iron atoms in the phase composition of nanoparticles had a positive effect after seed treatment on the resistance of white cabbage cultivar Penca de Povoa to blackleg disease when plants 
were grown in a substrate infected with fungal root rot pathogens. The influence of the size, shape, and phase composition of magnetic iron oxide nanoparticles on the morphometric and biochemical parameters of plants, both during pre-sowing seed treatment and when processing vegetative plants with nanoparticles, is less obvious. However, the positive effect of oleic acid, oddly enough, is manifested in the fact that the best results in almost all parameters are achieved at lower concentrations of nanoparticles. All three variants of nanoparticles had a positive effect on the yield of cucumbers when used for foliar treatment of plants. It is interesting to note that it is the composite nanoparticles corresponding to the composition of the maghemitemagnetite solid solution with a shell of oleic acid that contributed to the highest productivity of cucumber plants. In the future, to enhance the phytoprotective effect, it is planned to test the effect of modifying the surface of iron oxide nanoparticles with various substances, such as silicon dioxide or carbon nanomaterials, which, if successful, will reduce the dose load of persistent agrochemicals and pesticides on the environment.

\section{Funding}

The present work was supported by the Russian Scientific Foundation, project №19-13-00442.

\section{Acknowledgments}

This research has no acknowledgment.

\section{Conflicts of Interest}

The authors declare no conflict of interest.

\section{References}

1. Khan, M.R.; Adam, V.; Rizvi, T.F.; Zhang, B.; Ahamad, F.; Josko, I.; Zhu, Y.; Yang, M.; M, C. Nanoparticle-Plant Interactions: Two-Way Traffic. Nanoparticles. Small 2019, 15, 1901794 DOI: 10.1002/smll.201901794

2. Palmqvist, N.G.M.; Bejai, S.; Meijer, J.; Seisenbaeva, G.A.; Kessler, V.G. Nano Titania Aided Clustering and Adhesion of Beneficial Bacteria to Plant Roots to Enhance Crop Growth and Stress Management. Scientific Reports 2015, 5, https://doi.org/10.1038/srep10146.

3. Palmqvist, N.G.M.; Seisenbaeva, G.A.; Svedlindh, P.; Kessler, V.G. Maghemite Nanoparticles Acts as Nanozymes, Improving Growth and Abiotic Stress Tolerance in Brassica Napus. Nanoscale Research Letters 2017, 12, https://doi.org/10.1186/s11671-017-2404-2.

4. Tombuloglu, H.; Tombuloglu, G.; Slimani, Y.; Ercan, I.; Sozeri, H.; Baykal, A. Impact of manganese ferrite (MnFe2O4) nanoparticles on growth and magnetic character of barley (Hordeum vulgare L.). Environmental Pollution 2018, 243, 872-881, https://doi.org/10.1016/j.envpol.2018.08.096.

5. Vázquez-Núñez, E.; López-Moreno, M.L.; de la Rosa Álvarez, G.; and Fernández-Luqueño, F. Incorporation of Nanoparticles into Plant Nutrients: The Real Benefits. In: Agricultural Nanobiotechnology. ed. LópezValdez, F.; Fernández-Luqueño, F. (eds), Springer, Cham, 2018; pp 49-76, https://doi.org/10.1007/978-3319-96719-6.

6. De Souza, A.; Govea-Alcaide, E.; Masunaga, S.H.; Fajardo-Rosabal, L.; Effenberger, F.; Rossi, L.M.; Jardim, R.F. Impact of Fe3O4 nanoparticle on nutrient accumulation in common bean plants grown in soil. SN Applied Sciences 2019, 1, https://doi.org/10.1007/s42452-019-0321-y.

7. Shilova, O.A.; Khamova, T.V.; Panova, G.G.; Kornyukhin, D.L.; Anikina, L.M.; Artemyeva, A.M.; Udalova, O.R.; Galushko, A.S.; Baranchikov, A.E. Synthesis and Research of Functional Layers Based on Titanium Dioxide Nanoparticles and Silica Sols Formed on the Surface of Seeds of Chinese Cabbage. Russian Journal of Applied Chemistry 2020, 93, 25-34, https://doi.org/10.1134/S1070427220010036.

8. Semenov, K.N.; Meshcheriakov, A.A.; Charykov, N.A.; Dmitrenko, M.E.; Keskinov, V.A.; Murin, Igor V.; Panova, G.G.; Sharoyko, V.V.; Kanash, E.V.; Khomyakov, Y.V. Physico-chemical and biological properties of C60-1-hydroxyproline water solutions. RSC Advances 2017, 7, 15189-15200, https://doi.org/10.1039/C6RA26621E. 
9. Morales-Díaz, A.B.; Ortega-Ortíz, H.; Juárez-Maldonado, A.; Cadenas-Pliego, G.; González-Morales, S.; Benavides-Mendoza, A. Application of nanoelements in plant nutrition and its impact in ecosystems. Advances in Natural Sciences: Nanoscience and Nanotechnology 2017, 8, https://doi.org/10.1088/20436254/8/1/013001.

10. Yang, J.; Cao, W.; Rui, Y. Interactions between nanoparticles and plants: phytotoxicity and defense mechanisms. Journal of Plant Interactions $\quad 2017, \quad 12, \quad$ 158-169, https://doi.org/10.1080/17429145.2017.1310944.

11. Lu, K.; Shen, D.; Liu, X.; Dong, S.; Jing, X.; Wu, W.; Tong, Y.; Gao, S.; Mao, L. Uptake of iron oxide nanoparticles inhibits the photosynthesis of the wheat after foliar exposure. Chemosphere 2020, 259 (127445), https://doi.org/10.1016/j.chemosphere.2020.127445.

12. Tripathi, D.K.; Shweta; Singh, S.; Singh, S.; Pandey, R.; Singh, V.P.; Sharma, N.C.; Prasad, S.M.; Dubey, N.K.; Chauhan, D.K. An overview on manufactured nanoparticles in plants: Uptake, translocation, accumulation and phytotoxicity. Plant Physiology and Biochemistry 2017, 110, 2-12, https://doi.org/10.1016/j.plaphy.2016.07.030.

13. Kahrariyan, B.; Yeganehpoor, F.; Beyginiya, V.; Samadiyan, F. Effect of Fe Foliar Application on Morphological and Physiological Traits of Different Dryland Wheat Cultivars. International Journal of Advanced Biological and Biomedical Research 2013, 1, 1583-1589.

14. Janmohammadi, M.; Amanzadeh, T.; Sabaghnia, N.; Dashti, S. Impact of foliar application of nano micronutrient fertilizers and titanium dioxide nanoparticles on the growth and yield components of barley under supplemental irrigation. Acta agriculturae Slovenica 2016, 107, 265-276, http://dx.doi.org/10.14720/aas.2016.107.2.01.

15. Wang, Y.; Wang, S.; Xu, M.; Xiao, L.; Dai, Z.; Li, J. The impacts of $\gamma$-Fe2O3and Fe3O4 nanoparticles on the physiology and fruit quality of muskmelon (Cucumis melo) plants. Environmental Pollution 2019, 249, 1011-1018, https://doi.org/10.1016/j.envpol.2019.03.119.

16. Tombuloglu, H.; Slimani, Y.; Tombuloglu, G.; Almessiere, M.; Baykal A. Uptake and translocation of magnetite ( $\mathrm{Fe} 3 \mathrm{O} 4)$ nanoparticles and its impact on photosynthetic genes in barley (Hordeum vulgare L.). Chemosphere 2019, 226, 110-122. https://doi.org/10.1016/j.chemosphere.2019.03.075.

17. Tombulogu, H.; Slimani, Y.; AlShammari, T.M.; Bargouti, M.; Ozdemir, M.; Tombulogu, G.; Akhtar, S.; Sabit, H.; Hakeem, K.R.; Almessiere, M.; Ercan, I.; Baykal, A. Uptake, translocation, and physiological effects of hematite $\left(\mathrm{a}-\mathrm{Fe}_{2} \mathrm{O}_{3}\right.$ ) nanoparticles in barley (Hordeum vulgare L.). Environmental Pollution 2020, 266, 115391, https://doi.org/10.1016/j.envpol.2020.115391.

18. Lyutoev, A.A.; Smirnov, Y.G. Development of the Technological Scheme of Sewage Treatment from Oil Pollution with the Use of Magnetic Nanoparticles. Neftegazovoe Delo (Oil and Gas Business): Electronic Scientific Journal 2013, 4, 424-435.

19. Etale, A.; Tutu, H.; Drake, D.C. Application of maghemite nanoparticles as sorbents for the removal of $\mathrm{Cu}(\mathrm{II}), \mathrm{Mn}(\mathrm{II})$ and $\mathrm{U}(\mathrm{VI})$ ions from aqueous solution in acid mine drainage conditions. Applied Water Science 2016, 6, 187-197, https://doi.org/10.1007/s13201-014-0217-3.

20. Halbreich, A.; Roger, J.; Pons, J.N.; Geldwerth, D.; Da Silva, M.F.; Roudier, M.; Bacri, J.C. Biomedical applications of maghemite ferrofluid. Biochimie 1998, 80, 379-390, https://doi.org/10.1016/S03009084(00)80006-1.

21. Mahmoudi, M.; Sant, S.; Wang, B.; Laurent, S.; Sen, T. Superparamagnetic iron oxide nanoparticles (SPIONs): Development, surface modification and applications in chemotherapy. Advanced Drug Delivery Reviews 2011, 63, 24-46, https://doi.org/10.1016/j.addr.2010.05.006.

22. Kumar, C.S.S.R. Magnetic nanomaterials. Wiley-VCH: Weinheim, Germany, 2009; pp. 633-648

23. Múzquiz-Ramos, E.M.; Guerrero-Chávez, V.; Macías-Martínez, B.I.; López-Badillo, C.M.; García-Cerda, L.A. Synthesis and characterization of maghemite nanoparticles for hyperthermia applications. Ceramics International 2015, 41, 397-402, https://doi.org/10.1016/j.ceramint.2014.08.083.

24. Rui, M.; Ma, C.; Hao, Y.; Guo, J.; Yukui, R.; Tang, X.; Zhao, Q.; Fan, X.; Zhang, Z.; Tianqi, H.; Zhu, S. Iron Oxide Nanoparticles as a Potential Iron Fertilizer for Peanut (Arachis hypogaea). Frontiers in Plant Science 2016, 7, https://doi.org/10.3389/fpls.2016.00815.

25. Shokrollahi, H. A review of the magnetic properties, synthesis methods and applications of maghemite. Journal of Magnetism and Magnetic Materials 2017, 426, 74-81, https://doi.org/10.1016/j.jmmm.2016.11.033.

26. Nazari, M.; Ghasemi, N.; Maddah, H.; Motlagh, M.M. Synthesis and characterization of maghemite nanopowders by chemical precipitation method. Journal of Nanostructure in Chemistry 2014, 4, https://doi.org/10.1007/s40097-014-0099-9.

27. Ramos Guivar, J.; Martinez, A.; Osorio, A.; De Los Santos Valladares, L.; Félix, L.; Bustamante, A. Structural and Magnetic Properties of Monophasic Maghemite ( $\gamma$-Fe2O3) Nanocrystalline Powder. Advances in Nanoparticles 2014, 03, 114-121, http://dx.doi.org/10.4236/anp.2014.33016.

28. Frison, R.; Cernuto, G.; Cervellino, A.; Zaharko, O.; Colonna, G.M.; Guagliardi, A.; Masciocchi, N. Magnetite-Maghemite Nanoparticles in the 5-15 nm Range: Correlating the Core-Shell Composition and the Surface Structure to the Magnetic Properties. A Total Scattering Study. Chemistry of Materials 2013, 25, 4820-4827, https://doi.org/10.1021/cm403360f. 
29. Liu, S.; Wu, G.; Chen, H.-Z.; Wang, M. Preparation and characterization of Fe3O4/SiO2 particles for dualparticle electrophoretic display. Synthetic Metals 2012, 162, 89-94, https://doi.org/10.1016/j.synthmet.2011.11.016..

30. Panova, G.G.; Shilova, O.A.; Nikolaev, A.M.; Kovalenko, A.S.; Udalova, O.R.; Anikina, L.M.; Zhuravleva, A.S.; Khomyakov, Yu. V.; Vertebnyi, V.E.; Dubovitskaya V.E. On the impact of Iron Oxide Nanoparticles on Plants in the Vegetative Period of Development. Agrofizika 2019, 3, 40-50, https://doi.org/10.25695/AGRPH.2019.03.07.

31. Shilova, O.A.; Nikolaev, A.M.; Kovalenko, A.S.; Sinel'nikov, A.A.; Kopitsa, G.P.; Baranchikov, A.E. Synthesis of Magnetic Nanopowders of Iron Oxide: Magnetite and Maghemite. Russian Journal of Inorganic Chemistry 2020, 65, 426-430, https://doi.org/10.1134/S0036023620030134.

32. Shilova, O.A.; Panova, G.G.; Khamova, T.V.; Nikolaev, A.M.; Kovalenko, A.S.; Kornyukhin, D.L.; Artem'eva, A.M.; Anikina L.M.; and Udalova, O.R.Sol-Gel-derived powders and suspensions for treatment plants. Abstracts of the XV Conference and Exhibition of the European Ceramic Society (XV ECerS Conference), Torino 2019.

33. Shilova, O.A.; Nikolaev, A.M.; Kovalenko, A.S.; Khamova, T.V.; Kopitsa G.P.; and Panova, G.G. Synthesis, Properties and Application of Iron Oxides Magnetic Nanoparticles and Composites on Their Basis, Abstracts of the XXI Mendeleev Congress on General and Applied Chemistry. Book 2a: Chemistry and Technology of Materials: Abstracts, Saint Petersburg, 2019.

34. Bilay V.I. Methods of Experimental Mycology. Kiev: Naukova Dumka. 1982.

35. Ignatov, A.N.; Dr. Biolog. Sci. Thesis, Russian State Agrarian University - Timiryazev Agricultural Academy, Moscow, 2006.

36. Sazonova, L.V. VIR Methodological Guidelines. Study and Maintenance of a Collection of Vegetable Plants (Carrots, Celery, Parsley, Parsnips, Radishes). VIR: Leningrad, Russia, 1981, 190 p. (in Russian)

37. Hartmann, H.T.; Kester, D.E.; Davies, F.T.; Geneve, R.L. Plant propagation: Principles and Practices. London, 6th ed. Upper Saddle River, N.J.: Prentice-Hall International, 1997; pp. 770.

38. ISTA, International Rules for Seed Testing, 2016.

39. RU Patent, 108 705, 2010.

40. RU Patent, 2081 555, 1997.

41. Chesnokov, V.A.; Bazyrina, E.N.; Bushueva T.M. Growing Plants without Soil. Leningrad State University, Leningrad, 1960, pp. 170.

42. Ermakov, A.I.; Arasimovich, V.V.; Yarosh, N.P.; Peruanskii, Y.V.; Lukovnikova, G.A.; Ikonnikova, M.I. Methods for Biochemical Research of Plant. Agropromizdat, Leningrad, 1987; pp. 430.

43. Tutel' yan, V.A.; Belyaev, E.N. Guidance on Methods for Analyzing Food Quality and Safety. ed. Skurikhin, I.M.; Tutel' yan, V.A. Moscow, Russian Academy of Medical Sciences, Institute of Nutrition, Brandes: Meditsina, 1998; pp. 341.

44. Nasrazadani, S.; Raman, A. The application of infrared spectroscopy to the study of rust systems-II. Study of cation deficiency in magnetite (Fe3O4) produced during its transformation to maghemite $(\gamma$-Fe2O3) and hematite ( $\alpha$-Fe2O3). Corrosion Science 1993, 34, 1355-1365, https://doi.org/10.1016/0010-938X(93)90092$\mathrm{U}$.

45. Jafari, A.; Farjami Shayesteh, S.; Salouti, M.; Boustani, K. Dependence of structural phase transition and lattice strain of Fe3O4 nanoparticles on calcination temperature. Indian Journal of Physics 2015, 89, 551560, https://doi.org/10.1007/s12648-014-0627-y.

46. Pecharromán, C.; González-Carreño, T.; Iglesias, J.E. The infrared dielectric properties of maghemite, $\gamma$ Fe2O3, from reflectance measurement on pressed powders. Physics and Chemistry of Minerals 1995, 22, 21-29, https://doi.org/10.1007/BF00202677.

47. Anthony, J.W.; Bideaux, R.A.; Bladh, K.W.; Nichols, M.C. Handbook of Mineralogy, Mineralogical Society of America, Chantilly, VA.

48. Gómez-Polo, C.; Larumbe, S.; Barquín, L.F.; Fernández, L.R. Magnetic induction heating as a new tool for the synthesis of Fe3O4-TiO2 nanoparticle systems. Journal of Nanoparticle Research 2016, 18, https://doi.org/10.1007/s11051-016-3426-X.

49. Baas, J.M.A. A Guide to the Complete Interpretation of Infrared Spectra of Organic Structures. N.P.G. Roeges. John Wiley, Chichester, 1994. 340 pp., £45.00. ISBN 0-471-93998-6. Recueil des Travaux Chimiques des Pays-Bas 1995, 114, 114-114, https://doi.org/10.1002/recl.19951140311.

50. Stuart, B. Infrared Spectroscopy: Fundamentals and Applications. John Wiley \& Sons, Ltd, Chichester: 2004; pp. 203, https://doi.org/10.1002/0470011149.

51. Cornell, R.M.; Schwertmann, U. The Iron Oxides. Wiley-VCH Verlag GmbH \& Co, Weinheim, 2003; pp. 694, https://doi.org/10.1002/3527602097.

52. Jarlbring, M.; Gunneriusson, L.; Hussmann, B.; Forsling, W. Surface complex characteristics of synthetic maghemite and hematite in aqueous suspensions. Journal of Colloid and Interface Science 2005, 285, 212217, https://doi.org/10.1016/j.jcis.2004.11.005.

53. Jubb, A.M.; Allen, H.C. Vibrational Spectroscopic Characterization of Hematite, Maghemite, and Magnetite Thin Films Produced by Vapor Deposition. ACS Applied Materials \& Interfaces 2010, 2, 2804-2812, https://doi.org/10.1021/am1004943. 
54. Roonasi, P.; Holmgren, A. A study on the mechanism of magnetite formation based on iron isotope fractionation. TMS Annual Meeting 2009, 829-836.

55. Kahani, S.A.; Yagini, Z. A Comparison between Chemical Synthesis Magnetite Nanoparticles and Biosynthesis Magnetite. Bioinorganic Chemistry and Applications 2014, 2014, https://doi.org/10.1155/2014/384984.

56. Zhernovoy, A.I.; Naumov, V.N.; Rudakov, Y.R. Paramagnetic Nanoglobules Dispersion Curve Definition via Magnetization and Magnetizable Field Using NMR Method. Nauchnoe Priborostroenie (Science Instrumentation) 2009, 19, 57-61. 